\title{
Makt og innflytelse i prosessen med å endre strukturen i yrkesopplæringen
}

Likeverdige forfattere:

Kari Hansen, Grete Haaland og Inger Vagle 


\section{Sammendrag}

Artikkelen handler om endringsprosessen i utforming av ny struktur i yrkesopplæringen og på hvilken måte fagmiljøene og bransjene, gjennom de faglige rådene, har innflytelse på endringene i struktur som gjøres i norsk yrkesopplæring. Beslutningsprosessen ses i lys av ILO-konvensjonen av 1975, som forplikter statene til at fagmiljøene og bransjene skal ha stor innflytelse på yrkesopplæringens innhold og struktur. Konvensjonen forplikter medlemsstatene til utforming av politikk, retningslinjer og tiltak i yrkesopplæringen i samarbeid med fagmiljøene og bransjene.

Begrunnelse for studien er funn fra tidligere forskning og vår erfaring med at aktørene i yrkesopplæringen ikke systematisk er involvert i endringsprosessene. Vi ønsker å studere hvordan prosessen med strukturendringene foregår og hva som påvirker prosessen fram mot endelig struktur.

Metoder i forskningsarbeidet er analyse av tidligere forskning og dokumenter som ligger til grunn for, og inngår i, den formelle endringsprosessen, samt intervjuer med representanter for de nasjonale faglige rådene.

Resultatene viser at det er stor forskjell på hvordan fagmiljøene har hatt innflytelse i endringsprosessen og at endringsprosessen ikke har fulgt en forutbestemt prosedyre.

Partene, representert ved de faglige rådene, har i ulik grad hatt innflytelse på endringsprosessen. Tendenser viser at nasjonale myndigheter fristiller seg fra et forpliktende trepartssamarbeid i beslutningsprosessene ved flere anledninger.

Emneord: Trepartssamarbeid, faglighet, yrkesopplæring, strukturendring, makt

\section{Innledning}

Norsk yrkesopplæring står overfor store endringer, og ny struktur var på plass våren 2018. De åtte yrkesfaglige utdanningsprogrammene skal endres på bakgrunn av ny kunnskap om kompetansebehov i framtidens arbeidsliv, evaluering av Kunnskapsløftet og forskning bestilt av Utdanningsdirektoratet. Kunnskapsdepartementets begrunnelse for endringsarbeidet er at 1) det er stor variasjon i overgangen fra Vg2 til lære, gjennomføring og forankring i arbeidslivet 2) en mer relevant struktur kan gjøre opplæringen mer attraktiv for arbeidslivet. 
Artikkelen handler om prosessen fram mot fastsatt ny struktur i yrkesopplæringen og hvilke forhold som påvirker beslutningsprosessene. Vår motivasjon for denne studien er å finne ut hvilken innflytelse fagmiljøene har på endringene i norsk yrkesopplæring med tanke på kvalitet og kvalitetsutvikling i framtidens yrkesopplæring. Studien belyser hvordan beslutninger blir tatt i prosessen med endring av strukturen i yrkesopplæringen, hvordan fagmiljøene har innflytelse på prosessen og hva beslutningene er basert på. Fagmiljøene er i denne sammenheng bransjene som eier fagene, som er representert ved partene i arbeidslivet, og som består av fagarbeidere i de ulike lærefagene. Vi vil belyse hvordan fagmiljøene har innflytelse på endringene som gjøres i yrkesopplæringen.

\section{Problemstilling}

På hvilken måte har fagmiljøene og bransjene innflytelse på endringene i struktur som gjøres i norsk yrkesopplaring?

Forskningsspørsmål:

Hvilken innflytelse har fagmiljøene gjennom trepartssamarbeidet i de nasjonale faglige rådene?

\section{Metode}

En flermetodisk fenomenologisk forskningstilnærming ble anvendt i form av dokumentanalyse og semistrukturerte gruppeintervjuer (Postholm, 2010). Fenomenologisk forskning handler om å finne den sentrale underliggende meningen eller essensen $\mathrm{i}$ en opplevd erfaring (Postholm, 2010).

I den innledende fasen av studien analyserte vi styringsdokumenter, rapporter og utredninger knyttet til pågående endringsprosess i yrkesopplæringen (Grønmo, 2015; Thagaard, 2009; Kjeldstadli,1999). Semistrukturerte intervjuer ble gjennomført med representanter fra arbeidsutvalgene i syv av De faglige rådene. (Faglige råd er rådgivende organ for Utdanningsdirektoratet om faglige spørsmål knyttet til yrkesopplæringen i hvert av de yrkesfaglige utdanningsprogrammene.)

\section{Dokumentanalyse}

Vi valgte en fenomenologisk tilnærming til materialet og har derfor lest materialet fortolkende for å få fram innholdet (Johannessen, Tufte \& Christoffersen, 2016). Dokumentanalysen er en systematisk undersøkelse av innholdet i sentrale dokumenter for 
strukturendringen i yrkesopplæringen og har til hensikt å kategorisere, registrere og analysere innholdet (Grønmo, 2015). Johannessen, Tufte og Christoffersen (2016) skiller ikke mellom dokumentanalyse og analyse av annen type kvalitative data i tekstform, noe vi heller ikke gjorde. Hensikten er i begge tilfellene å få fram meningsinnholdet i teksten med fokus på innholdet i forskningsspørsmålene og på innflytelse. Dokumentene som inngår i analysen presenteres kort innledningsvis under overskriften Resultater og analyse av endringsprosessen.

\section{Semistrukturert gruppeintervju}

Vi gjennomførte semistrukturerte gruppeintervjuer med hele eller deler av arbeidsutvalgene for alle de faglige rådene unntatt rådene for Naturbruk og Medier og kommunikasjon. Begrunnelsen for dette var at Naturbruk var i en annen parallell endringsprosess som grunnlag for eventuelle endringer, og at utdanningsprogram Medier og kommunikasjon var slått sammen med utdanningsprogram for Design og håndverk (DH). De faglige rådene som var med i studien, representerte Bygg- og anleggsteknikk (BA), Design og håndverk (DH), Teknikk og industriell produksjon (TIP), Restaurant- og matfag (RM), Helse- og oppvekstfag (HO), Elektrofag (EL) og Service og samferdsel (SS). To forskere deltok ved alle intervjuene med unntak av faglig råd for Elektrofag. Intervjuene ble gjennomført tidlig i prosessen, før forslag til ny strukturen var klar.

Alle intervjuene omhandlet de samme temaene. De faglige rådene ble invitert til refleksjon omkring deres erfaringer med og meninger om yrkesopplæringen knyttet til eget utdanningsprogram. Intervjuene med representanter fra de faglige rådene ble gjennomført før juli i 2015. Spørsmålene vi utformet var inn mot trepartssamarbeidet og partenes opplevelse av innflytelse og involvering på innhold og struktur i yrkesopplaringen. I tillegg var vi interessert $i$ å få bedre innsyn i rådenes erfaringer med dagens yrkesopplaring $i$ eget utdanningsprogram og deres tanker om framtidig struktur i yrkesopplaringen. Spørsmålene var ikke detaljert utformet, men fungerte som en tematisk guide som hjelp til framdriften underveis i intervjuprosessen (Kvale \& Brinkmann, 2017).

\section{Analyse av data}

I dokumentanalysen var fokus på forslag til og begrunnelse for framtidig struktur i yrkesopplæringen. På bakgrunn av dokumentanalysen blir den faktiske kronologien i endringsprosessen beskrevet, som grunnlag for å kunne drøfte de ulike aktørenes innflytelse. Analysen av datamaterialet fra de semistrukturerte gruppeintervjuene ble gjennomført i 
fellesskap. For å finne mønster og redusere materialet slik at det ble oversiktlig, håndterlig og presentabelt, ble teksten kodet (Postholm, 2010; Kvale \& Brinkmann, 2017).

\section{KODING OG KATEGORISERING}

Koding anses å være den sentrale koblingen mellom å samle data og utvikle en gryende teori som forklarer disse dataene (Charmaz, 2006). Grunnlaget for analysen var basert på spørsmålene i intervjuguiden og forskningsspørsmålene og omhandlet: 1) respondentenes opplevelse av innflytelse i forhold til hverandre og i forhold til nasjonale myndigheter og 2) forslag til og begrunnelse for framtidig struktur i yrkesopplaringen. Kodingen innebar at det ble skrevet ned ord i tilknytning til gjennomlesingen som best definerte den opplevelsen som blir beskrevet av informanten. Eksempel på kodeord var «opplever seg som likeverdig innad $i$ rådet», eller «godt klima innad», og «stort sett enige», eller «rådet фnsker mer innflytelse» og «jobber hardt for å få mer makt». Gjennom prosessen utviklet vi en tabell med ytringene i en kolonne og kodeordene i en annen. Fremgangsmåten i denne prosessen var en grundig gjennomlesing av utsagn, for deretter å skrive våre kommentarer til teksten. Etter at kommentarene til teksten var kommet på plass, kategoriserte vi disse i samsvar med forskningsspørsmålene. Kategorisering innebærer at informasjon om det samme temaet samles i en kategori (Charmaz, 2006). Et skille i materialet var at de faglige rådene opplevde å samarbeide godt internt, samtidig som de på den andre siden ønsket større innflytelse og makt inn mot Utdanningsdirektoratet og Kunnskapsdepartementet. De to hovedkategorier er: Samarbeid internt i de faglige rådene og reell makt og innflytelse endringsprosessen.

Intervjuene ble parafrasert, og et kort, fokusert sammendrag presenteres sammen med resultatet av dokumentanalysen under hvert utdanningsprogram.

\section{ETIKK, VALIDITET OG RELIABILITET}

Studien er i sin helhet meldt inn til Norsk samfunnsvitenskapelig datatjeneste (NSD) og gjennomført i samsvar med deres retningslinjer. Studien er godkjent med prosjektnummer 43139.

Vi fulgte forskningsetiske prinsipper gjennom studien (Kvale \& Brinkmann, 2017).

Begrepene validitet og overførbarhet handler om å gjøre rede for og sikre at unders $\varnothing$ kelsen er troverdig og at funn som presenteres, er til å stole på (Malterud, 2006). Vi så analysearbeidet i lys av våre erfaringer fra yrkesutdanning i videregående skole og i bedrift, erfaringer som fagarbeidere i næringslivet innen Elektrofag og Design og håndverksfag. Forskerteamet har lang erfaring fra utdanningspolitisk arbeid, kvalitativ forskning og endringsarbeid innen 
yrkesfag, yrkesopplæring og yrkesfaglærerutdanning; praktisk pedagogisk utdanning for yrkesfag (PPUY) og treårig yrkesfaglærerutdanning (YFL).

Det ble gjort lydopptak av intervjuene. Intervjuene ble transkribert av en innleid person og anonymisert. Når studien er ferdigstilt, blir alle rådata makulert.

\section{Den formelle endringsprosessen i yrkesopplæringen}

I denne delen av artikkelen belyses oppdraget, fagmiljøenes og bransjenes formelle rolle og innflytelse gjennom trepartssamarbeidet i de faglige rådene og den formelle prosessen for endringer i yrkesopplæringen, (dokumentene som inngår i Utdanningsdirektoratets kunnskapsgrunnlag).

\section{Oppdraget - Fagfornyelsen}

Utdanningsdirektoratet fikk, som følge av melding til Stortinget 20 (2012-2013) På rett vei, i oppdrag fra Kunnskapsdepartementet å gjennomgå og gjøre nødvendige endringer i utdanningstilbudet for de yrkesfaglige utdanningsprogrammene, i samarbeid med partene i arbeidslivet. Meldingen viser at fag- og yrkesopplæringen i stor grad gir en kompetanse som verdsettes på arbeidsmarkedet. Den viser også at det er stor forskjell på yrkesfagene, og den har et spesielt fokus på de fagene som «verdsettes» lite i arbeidslivet. De fire utdanningsprogrammene Service og samferdsel, Helse- og oppvekstfag, Design og håndverk og Restaurant- og matfag er områder som Stortinget uttrykker behov for å få studert nærmere. Som del av oppdraget fra KD satte Utdanningsdirektoratet i gang forsknings- og utredningsarbeider som kunne tjene som kunnskapsgrunnlag for beslutningene om endringer i tilbudsstrukturen for den politiske ledelsen i Kunnskapsdepartementet. De nasjonale faglige rådene utarbeidet samtidig utviklingsredegjørelser om verdsetting av yrkesfagene $\mathrm{i}$ arbeidslivet innenfor sine respektive utdanningsprogram.

\section{Fagmiljøenes og bransjenes formelle rolle}

Bransjenes påvirkning av yrkesfaglig utdanning er regulert i The International Labour Convention (ILO 142), en konvensjon fra 1975 som forplikter statene til å utvikle systemer for samarbeid med arbeidslivets parter til utforming av politikk, retningslinjer og tiltak $i$ yrkesopplaringen. I Norge har staten og bransjene bestemt at den faglige innflytelsen skal ivaretas gjennom et trepartssamarbeid. Dette betyr at arbeidslivets parter skal ha rett til å 
påvirke beslutninger om struktur og innhold. De tre partene er arbeidstakere, arbeidsgivere og staten.

Fagenes og bransjenes innflytelse har endret seg over tid fra fullt selvstyre til mer statlig styring. Prinsippet om faglig selvstyre for fagmiljøene har vært en viktig rettesnor og «bærebjelke» i yrkesopplæringen siden den ble startet i sin tid. Dette dokumenteres blant annet av Ole Johnny Olsen i 2008 (Olsen, 2008) og Trine Deichman-Sørensen i 2015 (Deichman-Sørensen, 2015). Etter revisjonen av Lærlingeloven og innføring av Lov om fagopplæring i arbeidslivet, vedtatt i 1980, fikk vi et landsomfattende system for opplæring i arbeidslivet basert på faglig selvstyre. I realiteten handlet dette om et topartssamarbeid mellom arbeidstakere og arbeidsgivere, med staten som støttende part. Denne fornyelsesprosessen bidro til en mobilisering av aktører på alle nivå i arbeidslivet for deltakelse i fagopplæringens videre utvikling, og interessen for fagopplæringen ble betraktelig styrket i løpet av 1980-årene (Olsen, 2008). Særlig betydningsfullt var det at loven ivaretok arbeidslivets innflytelse gjennom fagopplæringens trepartssammensatte råd og utvalg. Rådet for fagopplæring i arbeidslivet (RFA) overtok Lærlingerådets vetorett ved utforming av læreplaner.

Fra Reform 94 har lærlingeordningen vært en integrert del av yrkesopplæringen, gjennom $2+2$ modellen som for de fleste lærefagene betyr to år i skole og to år i bedrift, som grunnlag for kvalifisering som godkjente fagarbeidere (Nyen \& Tøndel, 2014). Norge gikk dermed bort fra en fagopplæring med faglig selvstyre, til en statlig styring av både skole - og bedriftsopplæringen gjennom nasjonale læreplaner for det helhetlige utdanningsløpet i 2+2modellen. Norge har i dag en fagopplæring med statlig styring, en såkalt hybridmodell, som også innebærer at staten betaler for de to årene i skole og gir økonomisk støtte til de to siste årene med opplæring i bedrift gjennom lærlingtilskuddet (Olsen, 2011; Olsen, Høst \& Michalsen, 2008).

De partssammensatte faglige organene som inngår i det formelle beslutningssystemet i dag, er de faglige rådene. Disse rådene har et faglig ansvar for, og skal ha stor innflytelse på utvikling av strukturen i yrkesopplæringen (Udir, 2017). Utdanningsdirektoratet fastsetter mandat for de faglige rådene. Mandatet pålegger rådene et særskilt ansvar for å fremme forslag til endringer i læreplaner og tilbudsstruktur på Vg1, Vg2, og Vg3. På bakgrunn av vårt faglige fokus i artikkelen har vi valgt å ikke inkludere Samarbeidsrådet for yrkesopplæring (SRY) i vår analyse, da de har et overordnet ansvar og et mer strategisk 
perspektiv på yrkesopplæringen, men ikke har en rolle i den faglige prosessen vi har studert. I faglige spørsmål støtter SRY seg til de faglige rådene som er de formelle faglige og rådgivende organer i endringsprosessen.

\begin{tabular}{|c|c|c|c|}
\hline De faglige & & & \\
\hline rådene & & $\begin{array}{l}\text { Kunnskaps- } \\
\text { departementet }\end{array}$ & \\
\hline $\begin{array}{l}\text { Utviklings- } \\
\text { redegjørelser og } \\
\text { forslag til }\end{array}$ & $\begin{array}{l}\text { Utdannings- } \\
\text { direktoratet }\end{array}$ & (KD) & $\begin{array}{l}\text { Resultat etter } \\
\text { høring. Ny }\end{array}$ \\
\hline $\begin{array}{l}\text { Struktur } \\
3 \text { parts- } \\
\text { sammensatt }\end{array}$ & $\begin{array}{l}\text { Oppsummering } \\
\text { og forslag til } \\
\text { Kunnskaps- } \\
\text { departementet }\end{array}$ & $\begin{array}{l}\text { ble sendt til } \\
\text { hørings-instanser } \\
\text { via Utdannings- } \\
\text { direktoratet }\end{array}$ & $\begin{array}{l}\text { struktur for } \\
\text { yrkes- } \\
\text { opplæringen } \\
\text { besluttet }\end{array}$ \\
\hline
\end{tabular}

\section{Figur 1}

Figuren viser den formelle beslutningsprosessen

I den formelle beslutningsprosessen lager faglige råd utviklingsredegjørelser for sitt utdanningsprogram og forslag til struktur i framtidens yrkesopplæring, som sendes Utdanningsdirektoratet. Utdanningsdirektoratet bearbeider forslaget fra Faglige råd før de sender sin innstilling til Kunnskapsdepartementet. Kunnskapsdepartementet behandler forslaget fra Utdanningsdirektoratet og lager høringsutkast til struktur og gjennomfører høringsprosess, før de beslutter endelig struktur.

\section{Makt i endringsarbeidet}

Faglige perspektiver i endringsarbeidet utfordres blant annet av forhold knyttet til distriktspolitikk, ungdomsrett, økonomi og markedskrefter når beslutninger skal tas, blant annet gjennom rapportene fra de yrkesfaglige utvalgene, som beskrives på side elleve og tolv. I forbindelse med forarbeidet til innføring av Reform 94 ble forslag om brede grunnkurs og mer allmennfag i de yrkesfaglige programmene fremmet av partene $i$ arbeidslivet gjennom felleserklæringen til LO og NHO, og man kunne ane en økt interesse for yrkesopplæringen fra partene i arbeidslivet (Olsen, 2008). Felleserklæringen fra LO og NHO ble utformet på sentralt nivå og fremmet som intensjonserklæring. LO og NHO gikk inn for at elever som begynte på yrkesfag, skulle være garantert en mulighet til å fullføre sin utdanning. Samtidig ble det pekt på at en slik garanti forutsatte at partene i arbeidslivet fikk $\phi k t$ innflytelse på dimensjoneringen av antall elevplasser $i$ ulike opplaeringsl $\phi p$. Partene forutsatte videre at staten måtte bære en del av opplæringskostnadene i form av økonomiske tilskudd til 
lærebedriftene (Nyen \& Hagen Tøndel, 2014, s. 76). Mye av grunnlaget for Reform 94 ble lagt gjennom felleserklæringen i regi av LO og NHO av 31. oktober 1990 og Blegen-utvalget. I 2006 ble Kunnskapsløftet innført, med færre og enda bredere yrkesfaglige utdanningsprogrammer. Hovedstrukturen og prinsippene fra Reform 94 ble videreført $\mathrm{i}$ Kunnskapsløftet.

\section{Forskyvning av makt og faglig innflytelse i yrkesopplæringen}

Makt kan defineres som evne til å gjøre forskjell, nå et mål eller skape en virkning. Makten kommer til uttrykk enten gjennom direkte beslutnings- og tvangssituasjoner, eller indirekte gjennom symboler, institusjoner og sosiale strukturer. Symbolske og strukturelle maktforhold kan påvirkes og formes strategisk eller være utilsiktet og skjult for aktørene (NOU 2003:19). I denne studien belyses forholdet mellom formell og reell makt for fagmiljøene og bransjene i prosessen med utforming av den nye strukturen i yrkesopplæringen. Makt- og demokratiutredningen strukturerer sin konkretisering av maktforhold i tre overskrifter, selv om de i praksis kan være flere sider av samme sak: 1) politisk makt, 2) фkonomisk makt og 3) ideologisk makt.

Politisk makt beskrives som den institusjonaliserte og sentraliserte makten innen regulerte territorier og i mellomstatlige forhold. Det er en autoritativ makt, den ytrer seg som pålegg, lover, fordelingsvedtak og tildeling av rettigheter. Denne studien belyser statlige føringer for yrkesopplæringen og hvordan fagmiljøene har innflytelse på beslutninger i prosessen med utforming av ny struktur i yrkesopplæringen. Den norske statens investeringer i yrkesopplæringen de siste årene kan gi grunnlag for et større behov for statlig kontroll og styring (Østerud, Engelstad \& Selle, 2003). Dette gjelder også i arbeidslivet og kan sammenlignes med statlige pålegg og regler som gjelder der og de enkelte bransjenes særlige reguleringer (Sund, 2005). Herunder kommer også arbeidslivets og skolesystemets organisering gjennom fagforeninger, tillitsvalgtapparat osv. Den sentrale ressursen i denne formen for makt er evne til å styre og til å samle oppslutning, som kan være knyttet til tillitsvalgte, ledere, lærere og eiere. I denne studien er dette interessant, med tanke på hvem som representerer fagmiljøene i de faglige rådene og som dermed har innflytelse på utviklingen av faglig kvalitet i yrkesopplæringen og fagarbeid som resultat av yrkesopplæringen. Partene i de faglige rådene diskuterer for eksempel yrkesfagenes bærekraft og konsistens i yrkesopplæringen (Faglige råd, 2016), samtidig som alle elever mellom 15 og 19 år er rettighetselever og har rett til videregående opplæring i hele Norge. Disse forholdene kan stå i motsetning til hverandre og legge grunnlag for maktforskyvning. 
I denne studien kan ideologisk makt knyttes til hvordan ideologien blir ivaretatt gjennom prosessen i utforming av strukturen i framtidens yrkesopplæring. Ideologien kommer til syne gjennom grunnlagsdokumenter som Norges offentlige utredninger (NOU) og stortingsmeldinger, og handler i Fagfornyingen om blant annet relevans, konsistens, bærekraft og demokrati. Denne ideologien er partene enige om og ideologien skal ivaretas gjennom blant annet partenes innflytelse og deltagelse i de faglige rådene. Ideologien er under press fra mange hold, også i utdanningsreformer, gjennom for eksempel byråkratisering og markedsorientering og de faglige rådenes rolle i denne sammenheng er derfor viktig og interessant for denne studien.

I følge Deichman-Sørensen (2015) viser et historisk blikk på trepartssamarbeidets funksjon og rolle at makten har forskjøvet seg over tid. Partenes innflytelse i fag- og yrkesopplæring er ifølge Deichman-Sørensen (2015) i ferd med å endre seg. Hun har studert innføring av ny kvalitetsøkonomi i fagopplæringen fra ulike vinkler. Hun hevder det har skjedd en maktforskyvning over flere ledd. En forskyvning fra et tidligere partssamarbeid mot dagens statlige styringssystem. Olsen (2008) hevder at partsorganisasjonene, historisk sett, i liten grad har hatt sin hovedinteresse rettet mot kvalifikasjonspolitiske spørsmål. Virksomheten har i hovedsak vært styrt av tariffpolitiske forhold. Den påfølgende interessen fra partsorganisasjonene og fra politiske myndigheter har derfor ingen solid historisk forankring $\mathrm{i}$ trepartssamarbeid (Olsen, 2008).

Det har, ifølge Olsen, skjedd en gradvis statliggjøring av norsk yrkesopplærings institusjonelle orden. Den skolepolitiske innflytelsen i utdanningsforvaltningen er styrket, mens de fagopplæringspolitiske aktørenes aktivitet og formelle posisjon er snevret inn (Olsen, 2011). Norsk fag- og yrkesopplæring synes å være på vei til å bli et statlig regulert utdanningssystem. Olsen $(2008 ; 2011)$ mener dette $\emptyset$ ker risikoen for at systemet omgjøres til noe annet enn fagopplæring. Fagopplæringen er betydelig svekket, og norsk yrkesopplæring er på vei til å bli et rent statlig regulert utdanningssystem. Han hevder også at det er tegn som tyder på at det kan skje en form for langsom omdannelse gjennom mer skjulte og uforutsette mekanismer og virkninger (Olsen, 2011; 2008). At staten har utviklet større makt over utviklingen av fag- og yrkesopplæring, drøftes også i sluttrapporten for prosjektet Kvalitet $i$ fag-og yrkesopplaringen (Høst, 2015a), gjennom at bedriftene mottar statsstøtte, som kan resultere i økt statlig innflytelse og kontroll. Videre hevder Høst (2015a) at det norske fag- og yrkesutdanningssystemet har utviklet seg til et hybridsystem de siste 20 årene. Staten styrer, men det forutsettes at lærebedriften har en betydelig innflytelse. I denne studien belyses 
fagmiljøenes innflytelse på strukturendringene gjennom de faglige rådene og om forskyvningen av makt og innflytelse, som beskrives ovenfor, også gjelder forhold som har betydning for kvalitet i yrkesopplæringen. Trepartssamarbeidet belyser ikke som sådan i endringsprosessen, men fagmiljøenes innflytelse på fagutviklingen gjennom de trepartssammensatte faglige rådene. Studien belyser hvordan denne maktforskyvningen eventuelt har påvirket fagmiljøenes innflytelse på faglige forhold og kvalitet i lys av føringene om relevans og konsistens i yrkesopplæringen.

\section{Resultater og analyse av endringsprosessen}

Først presenteres dokumentene som inngår i analysen. Deretter presenteres funn og resultater fra dokumentanalysen og intervjuene med representanter fra sju av de faglige rådene, strukturert etter de ulike utdanningsprogrammene. I tabellene bak det enkelte utdanningsprogrammet beskrives aktivitetene i endringsprosessen i kronologisk rekkefølge, fra Kunnskapsdepartementets oppdrag til Utdanningsdirektoratet i 2014, til beslutningen om ny struktur ved politisk ledelse i KD våren 2017. Vår analyse av intervjuene tar hensyn til tidspunktet for aktivitetene i endringsprosessen, da de fleste intervjuene ble gjennomført på et tidlig tidspunkt i prosessen, før de yrkesfaglige "ekspert"-utvalgene som var oppnevnt av KD, hadde lagt fram sine forslag. Til slutt oppsummeres resultatet av prosessen fram til endelig resultat og ny struktur i yrkesopplæringen.

\section{Dokumentene som inngår i analysen}

Utdanningsdirektoratet startet sitt arbeid med endringsprosessen med å utvikle et kunnskapsgrunnlag basert på ulike aktiviteter gjennomført av ulike utvalg og miljøer. Utgangspunktet er Meld. St. 20 (2012-2013), en evaluering av dagens yrkesopplæring etter innføring av Kunnskapsløftet.

Kunnskapsgrunnlaget består av utviklingsredegjørelser fra de ni faglige rådene (Faglige råd 2016), bestillingsforskning som omhandler fire av de yrkesfaglige utdanningsprogrammene (Strøm Prestvik, Helgesen \& Rålmnibio, 2016; Høst, Reegård, Borgan, Skålholt \& Hagen Tøndel, 2015b; Reegård \& Høst, 2015,) og rapporter fra fem yrkesfaglige utvalg.

\section{UTVIKLINGSREDEGJøRELSER FRA DE NI FAGLIGE RÅDENE}

Utviklingsredegjørelsene inneholder svar på sentrale spørsmål fra Utdanningsdirektoratet om de forskjellige lærefagene i det utdanningsprogrammet som rådet representerer. Spørsmålene 
handlet blant annet om samfunnets behov for lærefaget i dag og i framtiden. De faglige rådene har vurdert hvordan lærefagene fungerer, hvorvidt de er relevante for arbeidslivet og samfunnets framtidige behov for lærefaget. Utviklingsredegjørelsene inneholder også rådenes anbefalinger til ny struktur.

\section{UTDANNINGSDIREKTORATET BESTILTE FORSKNINGSPROSJEKTER SOM DEL AV}

\section{KUNNSKAPSGRUNNLAGET FOR STRUKTURENDRINGEN}

Rapporten Yrkesutdanninger med svak forankring $i$ arbeidslivet, en kunnskapsoversikt som omhandler utdanningsprogrammene Design og håndverk, Helse- og oppvekstfag, Service og samferdsel og Restaurant- og matfag (Høst mfl., 2015b). Forskerne ser både på helheten i de nevnte utdanningsprogrammene, og på utfordringer knyttet til enkeltfag.

Kunnskapsoversikten innbefatter systematisering av eksisterende kunnskap om disse fire utdanningsprogrammene, som ble vurdert å ha særlige utfordringer knyttet til verdsetting i arbeidslivet og en beskrivelse av behov for mer ny kunnskap om fagområdene.

Den andre rapporten Fagopplaering eller statlig utdanning i arbeidslivet? Om laerefagene IKT Service og Kontor- og administrasjon var en dybdestudie av Kontor- og administrasjonsfaget og IKT-servicefaget, som var basert på det som omtales som kunnskapshull og ble identifisert i første del av forskningsoppdraget (Reegård \& Høst, 2015).

\section{SUPPLERENDE FORSKNING FOR Å DEKKE KUNNSKAPSBEHOVET}

I tillegg til de to bestilte forskningsarbeidene bestilte Utdanningsdirektoratet supplerende forskning for å utvikle nødvendig kunnskap for endringsarbeidet: 1) en undersøkelse av kompetansebehov blant lærlinger og faglærte i matindustrien Fag- og yrkesopplæring i matindustrien (Strøm Prestvik mfl., 2016), 2) Rapporten Rekruttering, frafall og overgang til laereplass på restaurant- og matfag (Andersen \& Andresen, 2016), 3) Rekruttering til designog håndverksfagene (Hagen Tøndel \& Skinnarland, 2016).

\section{RAPPORTER FRA YRKESFAGLIGE UTVALG}

Fem yrkesfaglige utvalg skulle sikre bred involvering og bringe inn innspill, diskusjoner og kunnskap fra aktører som ikke til vanlig er involvert i fag- og yrkesopplæringen. Utvalgene var delt inn i følgende næringsområder: a) helse, oppvekst og velvære, b) handel, kontor og service, c) reiseliv, matproduksjon og primærnæringen, d) bygg, elektro og industri, samt e) immateriell kulturarv og verneverdige fag. Å løfte fram særlige utfordringer og utviklingstrekk i bransjene var sentralt. Noen av utvalgene ga også konkrete anbefalinger til 
endringer i enkeltfag. Utvalgene var sammensatt av representanter for næringslivet. De fleste representerte arbeidsgiversiden, og fagarbeidere var i liten grad representert i utvalgene.

\section{UTDANNINGSDIREKTORATETS OPPSUMMERING OG ANALYSE AV KUNNSKAPSGRUNNLAGET}

Flere temaer som drøftes i Udirs analyse og anbefalinger handler i stor grad om prinsipper for tilbudsstrukturen. Temaene er for eksempel opprettelse av nye utdanningsprogrammer, $\emptyset \mathrm{kt}$ faglig spesialisering på Vg2, fordypning på Vg3 (opplæring i bedrift), nye veier til studiekompetanse, analyse av små fag, tilbudsstrukturen og kompetansesentre. Anbefalingene og drøftingene i dette dokumentet er grunnlaget for de vurderinger og valg Utdanningsdirektoratet har lagt til grunn for sine forslag til utdanningsprogram og fag.

\section{KUNNSKAPSDEPARTEMENTETS OPPSUMMERING AV UTDANNINGSDIREKTORATETS ANALYSE}

På bakgrunn av Utdanningsdirektoratets analyse av kunnskapsgrunnlaget, beskrev KD ved Dagfinn Hertzberg i foredrag ved HiOA 16. mai 2017 følgende ønsket effekt av strukturendringen

1. bedre samsvar med arbeidslivets behov for faglært kompetanse: a) en mer relevant opplæring rettet mot et yrke eller grupper av yrker og b) et konsistent opplæringsløp fra Vg1 til Vg3 med god progresjon fram til lærefag og yrker

2. mer motiverte elever

3. et godt grunnlag for fagopplæring i hele landet

4. at flere bedrifter i større grad skal benytte lærlingeordningen for å rekruttere arbeidskraft

KD konkretiserte disse føringene i tre vurderingskriterier, som grunnlag for vurdering av høringsuttalelser og forslag til struktur fra høringsinstansene. De tre vurderingskriteriene er 1) relevans, 2) bærekraft og 3) konsistens.

\section{Resultat - Den reelle beslutningsprosessen}

Den reelle beslutningsprosessen viser involvering av andre enn de organer som utgjør den formelle beslutningsprosessen, og at den formelle beslutningsprosessen dermed er fraveket $\mathrm{i}$ dette endringsarbeidet. Avviket fra den formelle beslutningsprosessen omfatter involvering av fem yrkesfaglige utvalg som utarbeider sine rapporter parallelt med de faglige rådenes arbeid med utviklingsredegjørelsene. De yrkesfaglige utvalgene representerer i liten grad 
partene og fagmiljøene, og rapporterer direkte til Utdanningsdirektoratet og KD. Forskning bestilles også parallelt med de faglige rådenes arbeid, som rapporterer direkte til Utdanningsdirektoratet. Parallelt med at KD beslutter ny struktur oppnevner de et nytt utvalg, Lied-utvalget, som utreder eventuelle endringsbehov i hele den videregående opplæringens struktur og innhold. Avviket fra den formelle beslutningsprosessen er delvis forårsaket av Utdanningsdirektoratets valg om å utvikle et omfattende kunnskapsgrunnlag. Den reelle prosessen for endringsarbeidet kan illustreres på følgende måte:

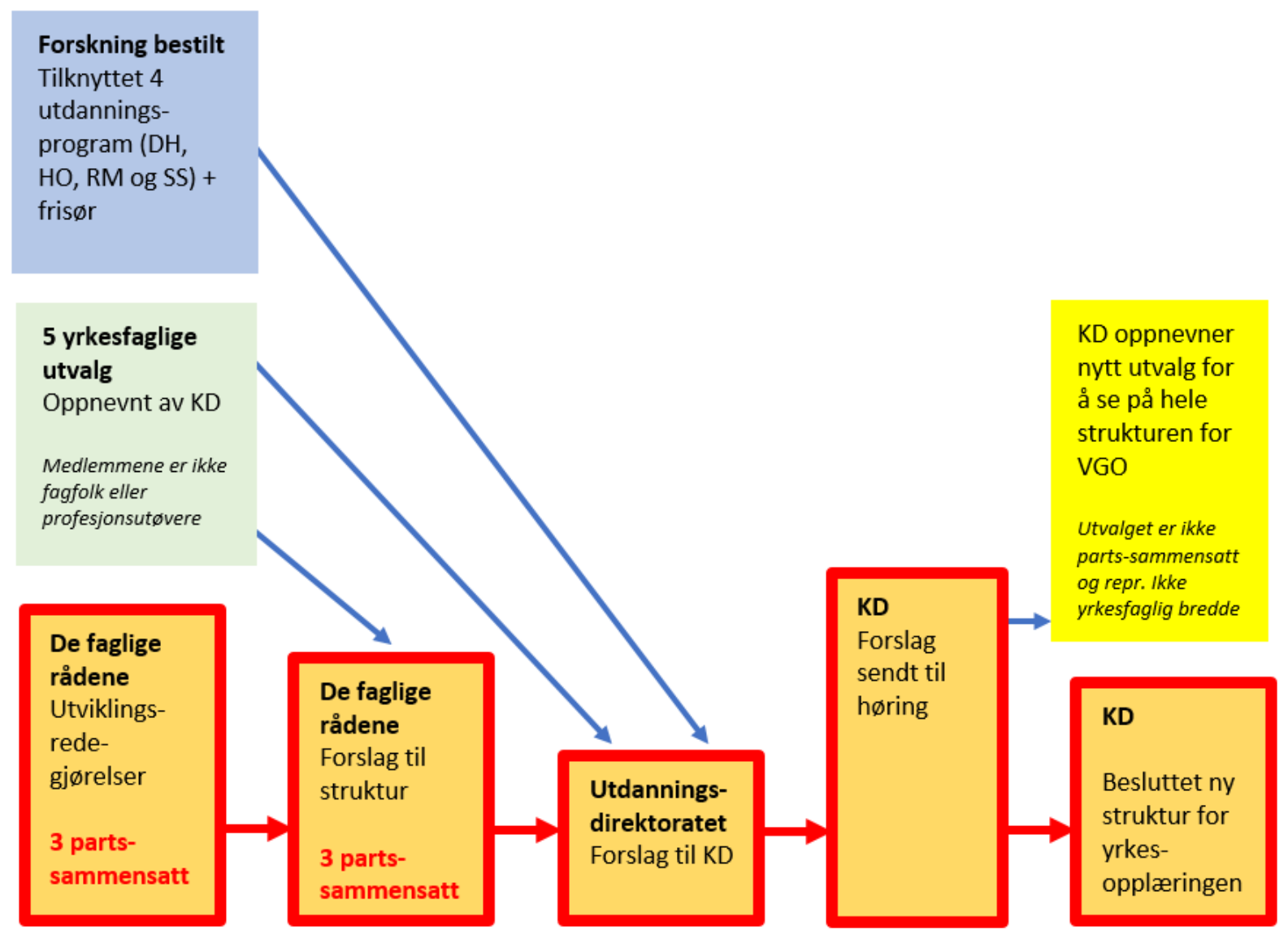

\section{Figur 2}

Den reelle beslutningsprosessen. Den formelle beslutningsprosessen er markert med røde rammer

\section{Fra kunnskapsgrunnlag til endelig struktur}

Kunnskapsdepartementet la 5. mars 2017 fram endelig struktur for yrkesopplæringen, hvor de har utvidet antall yrkesfaglige utdanningsprogram fra åtte til ti. De faglige rådene har tilhørighet til utdanningsprogrammene i dagens struktur. Endringene i ny struktur viser at Bygg- og anleggsteknikk, Elektro, Naturbruk og Restaurant og matfag blir omtrent som før på Vg1-nivå. Design og håndverk deles i to nye Vg1 og aktivitørfaget legges til utdanningsprogram for Helse- og oppvekstfag, som ellers blir som før Fagfornyingen. 
Service og samferdsel deles i to nye Vg1; Salg, service og reiseliv og IKT og medieproduksjon. To store lærefag; yrkessjåfør og Transport og logistikk, legges fra Service og samferdsel til TIP.

Endringene i ny struktur, som iverksettes høsten 2020, kan illustreres på følgende måte:

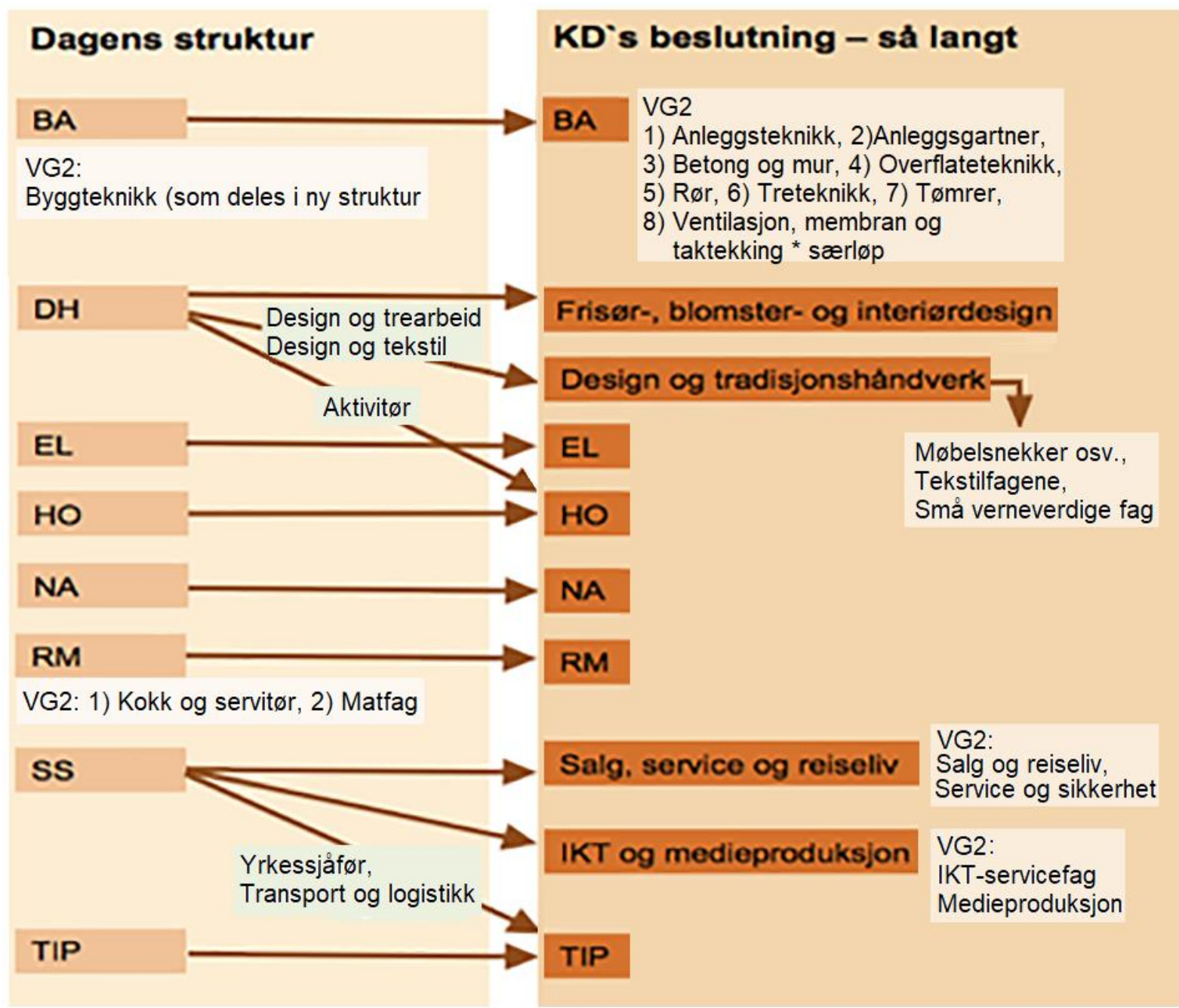

Figur 3

Åtte utdanningsprogram i dagens struktur for yrkesopplæringen endres til ti utdanningsprogram i Fagfornyelsen fra 2020. Figuren forklares i teksten

\section{Analyse av beslutningsprosessen i hvert av de yrkesfaglige utdanningsprogrammene}

Videre presenteres analyse av beslutningsprosessen knyttet til hvert enkelt utdanningsprogram, basert på dokumentanalysen og intervju med arbeidsutvalgene i de nasjonale faglige rådene. Den delen av ideologien som til en viss grad kan leses gjennom beslutningsprosessen er knyttet til deler av relevans- og konsistensbegrepet, ved at utdanningsprogrammene gjøres smalere og at lærefag som har mye til felles skal legges i 
samme utdanningsprogram. Det skal sikre relevans og sammenheng mellom sluttkompetansen i det lærefaget elevene utdanner seg til og opplæringen i både Vg1, Vg2 og Vg3. Bærekraft knyttes i Melding til Stortinget nr. 28 også til mulighetene for å gi god fagopplæring $\mathrm{i}$ hele landet, noe som kan ivaretas gjennom bredde i utdanningsprogrammene og delvis stå i konflikt til mulighetene for å oppnå relevans og konsistens. Det knyttes også til at det skal være mulig å få jobb etter endt utdanning, som i strukturen delvis kan ivaretas gjennom nedlegging av lærefag det ikke finnes jobber i.

\section{ENDRINGER I STRUKTUREN, UTDANNINGSPROGRAM B YGG- OG ANLEGGSTEKNIKK (BA)}

Figuren nedenfor viser analyseresultatet av endringsprosessen mot fastsatt struktur i utdanningsprogram Bygg- og anleggsteknikk (BA).

\begin{tabular}{|c|c|c|c|}
\hline $\begin{array}{l}\text { Faglig råd BAs } \\
\text { forslag }\end{array}$ & $\begin{array}{l}\text { Udirs } \\
\text { oppsummering }\end{array}$ & KDs høringsutkast & Endelig struktur \\
\hline $\begin{array}{l}\text { Bygg- og } \\
\text { anleggsteknikk }\end{array}$ & $\begin{array}{l}\text { Bygg- og } \\
\text { anleggsteknikk }\end{array}$ & $\begin{array}{l}\text { Bygg- og } \\
\text { anleggsteknikk }\end{array}$ & $\begin{array}{l}\text { Bygg- og } \\
\text { anleggsteknikk }\end{array}$ \\
\hline \multicolumn{4}{|l|}{ FRBA ønsker smalere Vg2 } \\
\hline Vg2: Anleggsteknikk & Vg2: Anleggsteknikk & Vg2: Anleggsgartner (alt1) & Vg2: Anleggsgartner \\
\hline Vg2: Betong og mur & Vg2: Betong og mur & Vg2: Anleggsteknikk (alt2), & Vg2: Anleggsteknikk \\
\hline Vg2: Overflateteknikk & Vg2: Overflateteknikk & (syv lærefag) & Vg2: Betong og mur \\
\hline Vg2: Rør & Vg2: Rør & Vg2: Betong og mur & Vg2: Overflateteknikk \\
\hline Vg2: Treteknikk & Vg2: Treteknikk & Vg2: Overflateteknikk & Vg2: Rør \\
\hline Vg2: Tømrer og stillas & Vg2: Tømrer og stillas & Vg2: Rør & Vg2: Treteknikk \\
\hline $\begin{array}{c}\text { Vg2: Ventilasjon, } \\
\text { membran og } \\
\text { taktekking }\end{array}$ & $\begin{array}{c}\text { Vg2: } \text { Ventilasjon, } \\
\text { membran og } \\
\text { taktekking }\end{array}$ & $\begin{array}{c}\text { Vg2: Møbel og treteknikk } \\
\text { (Møbel høres også i } \\
\text { forhold til Design og } \\
\text { tradisjonshåndverk) }\end{array}$ & $\begin{array}{l}\text { Vg2: Tømrerfaget } \\
\text { Vg2: Ventilasjon, } \\
\text { membran og } \\
\text { taktekking }\end{array}$ \\
\hline $\begin{array}{l}\text { FRBA foreslår at } \\
\text { anleggsgartner flyttes fra } \\
\text { NA til BA }\end{array}$ & $\begin{array}{l}\text { Vg3: Anleggsteknikk } \\
\text { (Tidligere } 5 \text { fag + } 2 \text { nye } \\
\text { fordypninger) }\end{array}$ & $\begin{array}{l}\text { Vg2: Tømrer og stillas } \\
\text { Vg2: Ventilasjon, } \\
\text { membran og } \\
\text { taktekking }\end{array}$ & \\
\hline $\begin{array}{l}\text { Renholdsoperatørfaget } \\
\text { blir særløp }\end{array}$ & $\begin{array}{l}\text { Renholdsoperatørfaget } \\
\text { blir særløp }\end{array}$ & $\begin{array}{l}\text { Forslag: Sammenslåing av } \\
\text { en del fag, men med } \\
\text { fordypninger }\end{array}$ & $\begin{array}{l}\text { Renholdsoperatørfaget og } \\
\text { stillasbyggerfaget blir } \\
\text { særløp }\end{array}$ \\
\hline
\end{tabular}

\section{Figur 4}

Beslutningsprosessen i utvikling av ny struktur for Bygg- og anleggsteknikk

I utdanningsprogram for Bygg- og anleggsteknikk er Faglig råd (FRBA), Udir og KD enige om at det fra 2020 skal være ett Vg1, som i dag. FRBA og Udir er også enige om Vg2løpene. Kunnskapsdepartementet er enig i høringsutkastet, mens de deler treteknikk i den endelige strukturen og legger møbelsnekker, treskjærer og trebåtbygger til Design og Tradisjonshåndverk. I BA har i all hovedsak det faglige rådet blitt hørt av både Udir og KD. Oppdelingen i flere $\mathrm{Vg} 2$ vil kunne gi et bedre grunnlag for relevant opplæring for lærefagene 
og kriteriene for relevans og konsistens kan dermed være ivaretatt De minste lærefagene er tatt ut og lagt til Design og Tradisjonshåndverk, og kriteriet om bærekraft synes å være ivaretatt i BA.

Faglig råd for BA uttrykker i intervjuet at de har fått beslutningsmyndighet til å gjøre en del ting, men jobber hardt for å få større innflytelse i faglige spørsmål. De opplever samarbeidet mellom partene som godt, men at de største lærefagene, blir mest hørt. "Altså Fellesforbundet har jo da halvparten av alle lærlingene som finnes i Norge. Drøfter mye, tar med seg standpunkter inn i egen organisasjon og prøver videre ...”.

FRBA synes å ha hatt reell innflytelse på strukturen i tråd med deres opplevelse av å ha fått beslutningsmyndighet $\mathrm{i}$ en del utdanningspolitiske saker.

\section{ENDRINGER I STRUKTUREN, UTDANNINGSPROGRAM DESIGN OG HÅNDVERK (DH)}

Figuren nedenfor viser analyseresultatet av endringsprosessen mot fastsatt struktur i utdanningsprogram Design og håndverk $(\mathrm{DH})$.

\begin{tabular}{|c|c|c|c|}
\hline $\begin{array}{l}\text { Faglig råd DHs } \\
\text { forslag }\end{array}$ & $\begin{array}{l}\text { Udirs } \\
\text { oppsummering }\end{array}$ & KDs høringsutkast & Endelig struktur \\
\hline $\begin{array}{l}\text { Frisør og } \\
\text { blomsterfag }\end{array}$ & $\begin{array}{l}\text { Frisør, hudpleie og } \\
\text { blomsterdekorering }\end{array}$ & Design & $\begin{array}{l}\text { Frisør, blomsterfag, } \\
\text { interiørdesign }\end{array}$ \\
\hline $\begin{array}{l}\text { Interiør, utstilling og } \\
\text { mediefag }\end{array}$ & $\begin{array}{l}\text { Interiør/utstilling legges } \\
\text { ned. IKT og mediefag blir } \\
\text { nytt Vg1 }\end{array}$ & $\begin{array}{l}\text { utstillingsdesign, } \\
\text { medieproduksjon) }\end{array}$ & $\begin{array}{l}\text { Vg2: Blomsterdekoratør } \\
\text { Vg2: Frisør } \\
\text { Vg2: Interiør- og } \\
\quad \text { utstillingsdesign }\end{array}$ \\
\hline $\begin{array}{l}\text { Metall- og } \\
\text { glasshåndverk }\end{array}$ & $\begin{array}{l}\text { Metall- og } \\
\text { glasshåndverk }\end{array}$ & $\begin{array}{l}\text { Tradisjonshåndverk } \\
\text { (Metall- og }\end{array}$ & $\begin{array}{l}\text { Design og } \\
\text { tradisjonshåndverk }\end{array}$ \\
\hline $\begin{array}{l}\text { Snekker og } \\
\text { trehåndverk }\end{array}$ & $\begin{array}{l}\text { Snekker og trehåndverk } \\
\text { flyttes til BA. Aktivitør } \\
\text { Vg2 flyttes til HO }\end{array}$ & $\begin{array}{l}\text { glasshăndverk, } \\
\text { snekker og } \\
\text { trehåndverk, søm- } \\
\text { og tekstilhåndverk, } \\
\text { duodji) }\end{array}$ & $\begin{array}{l}\text { Vg2: Børsemaker } \\
\text { Vg2: båtbygger } \\
\text { Vg2: Duodji }\end{array}$ \\
\hline $\begin{array}{l}\text { Søm og } \\
\text { tekstilhåndverk }\end{array}$ & $\begin{array}{l}\text { Søm og } \\
\text { tekstilhåndverk }\end{array}$ & & $\begin{array}{l}\text { Vg2: Gull- og } \\
\text { sølvsmedhåndverk } \\
\text { Vg2: Smed }\end{array}$ \\
\hline $\begin{array}{l}\text { Alle Vg1-løpene kan } \\
\text { rekruttere til Vg2 } \\
\text { Aktivitør og Duodji }\end{array}$ & Duodji & Aktivitør flyttes til HO & $\begin{array}{l}\text { Vg2: Søm- og } \\
\text { tekstilhåndverk } \\
\text { Vg2: Trearbeid } \\
\text { Vg2: Ur- og } \\
\text { instrumentmaker }\end{array}$ \\
\hline & & & + 12 særløp \\
\hline
\end{tabular}

\section{Figur 5}

Beslutningsprosessen mot fastsatt struktur i utdanningsprogram Design og håndverk $(\mathrm{DH})$ 
Faglig råd for Design og håndverk (FRDH) foreslår at dagens DH deles inn i fem nye Vg1. De vil samle de største lærefagene; frisør-, parykkmaker og blomsterdekoratørfaget, i samme utdanningsprogram, mens de andre fire blir små, sett i sammenheng med antall lærlinger pr. år. Kunnskapsdepartementets krav til bærekraft synes dermed å være ivaretatt i ett av de fem utdanningsprogrammene. Relevans og konsistens ivaretas på den måten at lærefagene de foreslår i de enkelte $\mathrm{Vg} 1$ synes å ha mer til felles enn lærefagene i dagens Vg1, som er adskillig bredere. Utdanningsdirektoratet foreslår at dagens DH deles inn i fire nye $\mathrm{Vg}$, to av de samme som FRDH. De foreslår imidlertid å flytte snekkerfagene til BA, legge ned interiør- og utstillingsdesign og å lage et nytt Vg1 for IKT og mediefag. De støtter FRDH på at frisør- og blomsterdekoratørfaget skal ha felles $\mathrm{Vg} 1$, men foreslår at hudpleiefaget skal flyttes fra Helse- og oppvekstfag til frisør og blomsterdekoratørfaget. KD foreslår i sitt høringsutkast at dagens DH deles i to nye Vg1: Design og Tradisjonshåndverk. I motsetning til FRDH er Udir og KD enige om at aktivitør skal flyttes til HO. Sammen med frisør- og blomsterfag foreslår KD at interiør og utstillingsdesign legges ned. Det samme gjelder medieproduksjon. KD bestemmer at dagens DH skal deles i to, helt likt med deres forslag i høringsutkastet, bortsett fra når det gjelder mediefagene, som de legger til et nytt $\mathrm{Vg} 1$, sammen med IKT-servicefaget. Her har FRDH ikke blitt hørt. KD foreslår ett utdanningsprogram hvor de største lærefagene samles og ett lite, hvor alle de små fagene er samlet. Relevans og konsistens ivaretas i det store utdanningsprogrammet hvor fagene har mye felles, mens det kan bli vanskeligere i Design og tradisjonshåndverk, hvor lærefagene er små og har lite felles. Det siste vil også gi distriktspolitiske utfordringer, da antall lærlinger i de små yrkesfagene er svært lavt på landsbasis og synes ikke å være bærekraftig i henhold til KDs føringer om at fagopplæringen skal kunne gjennomføres i hele landet.

Prosessen i utvikling av ny struktur ved utdanningsprogram for Design og håndverk (DH), viser at det er stor forskjell på forslagene fra det trepartssammensatte Faglige rådet for DH, Utdanningsdirektoratets oppsummering og forslag til KD og KDs høringsutkast. Det faglige rådet foreslår at $\mathrm{DH}$ deles i fem ulike $\mathrm{Vg} 1$, Utdanningsdirektoratet foreslår tre, mens $\mathrm{KD}$ foreslår i sitt høringsutkast at $\mathrm{DH}$ deles i to $\mathrm{Vg} 1$.

Gjennom intervjuet kommer det fram at partene opplever å bli hørt og respektert i det faglige rådet. FRDH opplever at de får fram det de er opptatt av, at de blir hørt og at det blir tatt tak i de sakene som legges fram for Utdanningsdirektoratet. 
Resultatet av dokumentanalysen viser at FRDH ikke har fått gjennomslag for sitt forslag. De har dermed i denne endringsprosessen ikke hatt innflytelse i tråd med deres opplevelse av å ha det, slik de beskriver det i intervjuet. En medvirkende årsak til at de ikke har nådd fram, kan være at forslaget ikke er i tråd med de tre kriteriene KD legger til grunn for sin vurdering av forslagene. FRDH har ikke blitt hørt av Udir, og KDs endelige struktur er ikke i tråd med hverken FRDH eller Udir sitt forslag. Konsistens, relevans og bærekraft synes å være ivaretatt gjennom smalere $\mathrm{Vg} 1$ bestående av yrkesfag med flere likhetstrekk enn i det gamle Vg1 Design og håndverk.

\section{ENDRINGER I STRUKTUREN, UTDANNINGSPROGRAM ELEKTRO (EL)}

Figuren nedenfor viser analyseresultatet av endringsprosessen mot fastsatt struktur i utdanningsprogram Elektro (EL).

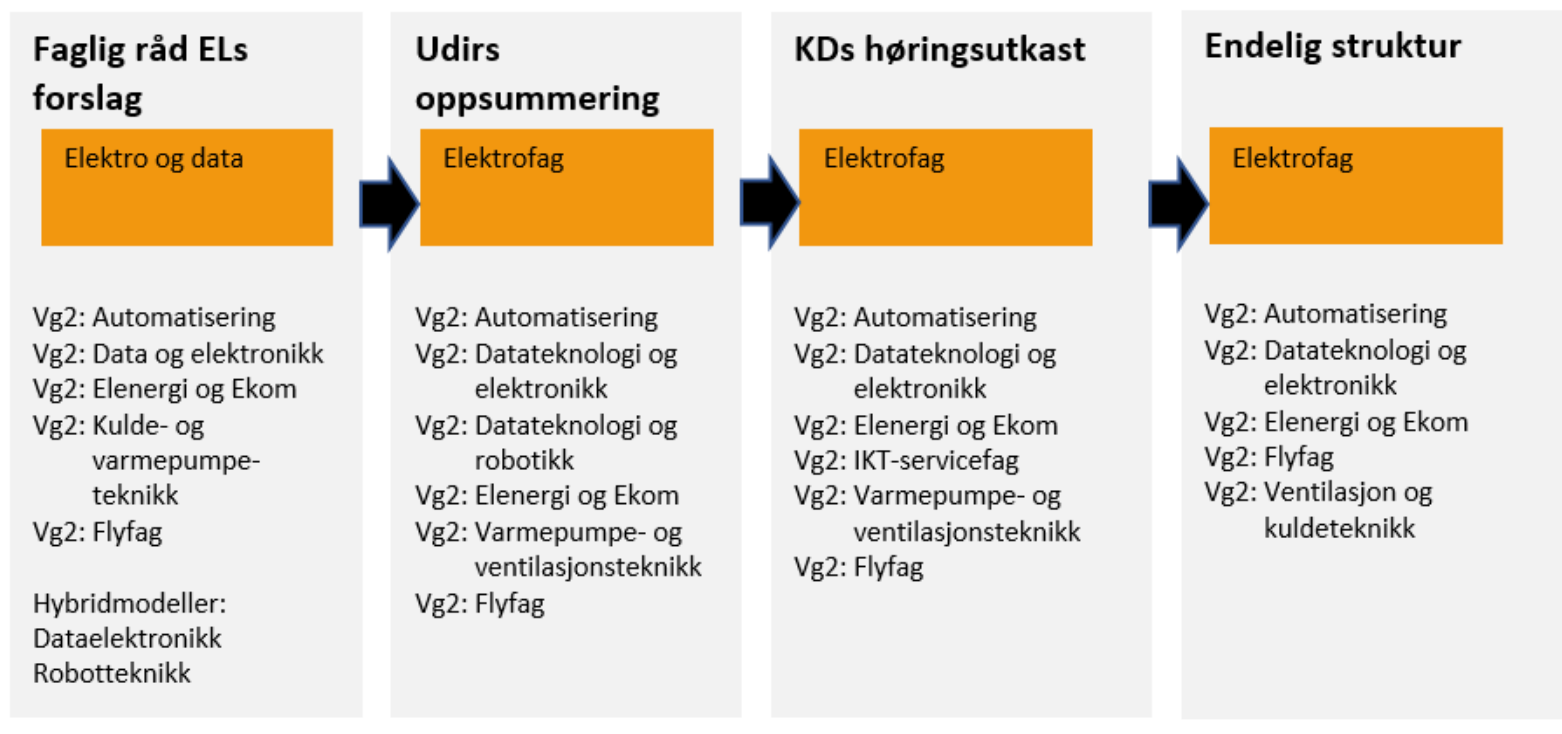

\section{Figur 6}

Beslutningsprosessen mot fastsatt struktur i utdanningsprogram Elektro (EL)

Faglig råd for elektro (FREL), Udir og KD er i hovedsak enige om det meste, deriblant strukturen og at Vg1 skal fortsette omtrent som i dag. Unntakene er blant annet navnet, hvor faglig råd foreslår Vg1 Elektro og data, mens Udir og KD er enige om at utdanningsprogrammet skal hete Vg1 Elektrofag. Innholdsmessig foreslår KD i motsetning til FREL og Udir at IKT-servicefag, fra det gamle Service og samferdsel, legges til Vg1

Elektrofag. I det endelige utkastet synes det som om FREL er hørt, bortsett fra når det gjelder hybridmodellene, navnet på utdanningsprogrammet og flytting av telekommunikasjonsfaget fra Vg2 Datateknologi og elektronikk til Vg2 Elenergi og Ekom. 
FREL uttrykker i intervjuet at de opplever å bli hørt, men ønsker mer avgjørende innflytelse, ikke bare rådgivende. De opplever at de har god integritet inn i Udir og at de har kolleger i rådet som fungerer godt sammen. Et eksempel på at de ikke blir hørt, er opplevelsen av at KD og Udir trenerer forslaget om fors $\varnothing \mathrm{k}$ med gjennomgående dokumentasjon. De opplever også at de ikke var involvert i en uheldig oppstart av endringsprosessen, slik det kom fram i intervjuet:

Prosessen i forkant er under enhver kritikk. De satte faglige råd til side og laget en parallell organisasjon som skulle levere produktet på samme tid. Det var ikke kommunikasjon underveis, bare utveksling av dokumenter, og på slutten skulle Udir sitte og velge de organisasjonene de ville høre på, og så fersket vi dem til en ren kopi av det danske utdanningssystemet (et medlem i faglig råd EL).

Strukturen som ble vedtatt av KD, er i all hovedsak i tråd med forslaget fra FREL og Udir. Det eneste FREL ikke fikk gjennomslag for, var de såkalte hybridmodellene, som skulle gjøre det mulig å velge to ulike veier mot generell studiekompetanse eller yrkeskompetanse, navnet på utdanningsprogramfaget og flytting av telekommunikasjonsfaget til vg2 Elenegi og Ekom. FREL er svært kritisk til manglende involvering og innflytelse i oppstart av endringsarbeidet, hvor KD v/statsråden startet en parallell prosess med opprettelse av yrkesfaglige utvalg som ikke var partssammensatt. KDs føringer om konsistens, relevans og bærekraft synes å være ivaretatt i Vg1.

\section{ENDRINGER I STRUKTUREN, UTDANNINGSPROGRAM HO}

Figur 7 viser analyseresultatet av endringsprosessen mot fastsatt struktur i utdanningsprogram Helse og oppvekstfag (HO). 


\begin{tabular}{|c|c|c|c|}
\hline $\begin{array}{l}\text { Faglig råd HOs } \\
\text { forslag }\end{array}$ & $\begin{array}{l}\text { Udirs } \\
\text { oppsummering }\end{array}$ & KDs høringsutkast & Endelig struktur \\
\hline $\begin{array}{l}\text { Helse- og } \\
\text { oppvekstfag }\end{array}$ & $\begin{array}{l}\text { Helse- og } \\
\text { oppvekstfag }\end{array}$ & $\begin{array}{l}\text { Helse- og } \\
\text { oppvekstfag }\end{array}$ & $\begin{array}{l}\text { Helse- og } \\
\text { oppvekstfag }\end{array}$ \\
\hline Vg2: Aktivitør & Vg2: Ambulansefag & Vg2: Aktivitør & Vg2: Aktivitør \\
\hline $\begin{array}{l}\text { Vg2: Barne- og } \\
\text { ungdomsarbeiderfag }\end{array}$ & $\begin{array}{l}\text { Vg2: Aktivitør } \\
\text { Vg2: Barne- og }\end{array}$ & $\begin{array}{l}\text { Vg2: Barne- og } \\
\text { ungdomsarbeiderfag }\end{array}$ & $\begin{array}{l}\text { Vg2: Ambulansefag* } \\
\text { Vg2: Barne- og }\end{array}$ \\
\hline $\begin{array}{l}\text { Vg2: Fotterapi og } \\
\text { ortopediteknikk } \\
\text { Vg2: Helsearbeiderfag }\end{array}$ & $\begin{array}{l}\text { ungdomsarbeiderfag } \\
\text { Vg2: Fotterapi og } \\
\text { ortopediteknikk }\end{array}$ & $\begin{array}{l}\text { Vg2: Fotterapi og } \\
\quad \text { ortopediteknikk } \\
\text { Vg2: Helsearbeiderfag }\end{array}$ & $\begin{array}{l}\text { VgL: Barne- og } \\
\text { ungdomsarbeiderfag } \\
\text { Vg2: Fotterapi og } \\
\text { ortopediteknikk }\end{array}$ \\
\hline Vg2: Helseservicefag & Vg2: Helsearbeiderfag & Vg2: Helseservicefag & Vg2: Helsearbeiderfag \\
\hline Vg2: Hudpleie & Vg2: Helseservicefag & Vg2: Hudpleie & $\begin{array}{l}\text { Vg2: Helseservicefag } \\
\text { Vg2: Hudpleie }\end{array}$ \\
\hline $\begin{array}{l}\text { Ambulanse foreslås som } \\
5 \text {-årig løp og utredes før } \\
\text { beslutning tas }\end{array}$ & $\begin{array}{l}\text { Hudpleie legges sammen } \\
\text { med frisør- og } \\
\text { blomsterdekoratør i nytt } \\
\text { utdanningsprogram }\end{array}$ & $\begin{array}{l}\text { Arbeid med forslag til ny } \\
\text { struktur for } \\
\text { ambulansefaget }\end{array}$ & $\begin{array}{l}\text { *Ny læringsmodell for } \\
\text { ambulansefaget } \\
\text { behandles i egen } \\
\text { prosess. Dagens modell } \\
\text { gjelder inntil videre }\end{array}$ \\
\hline
\end{tabular}

\section{Figur 7}

Viser beslutningsprosessen i utvikling av ny struktur for helse og oppvekstfag

Når det gjelder utdanningsprogram for Helse- og oppvekstfag, er Faglig råd for Helse- og oppvekstfag (FRHO), Udir og KD enige om at Vg1 skal være omtrent som i dag. Det ene unntaket er hudpleiefaget, som Udir foreslår lagt til Vg1, sammen med frisør- og blomsterdekoratørfaget, mens FRHO og KD er enige om at det skal ligge på HO. Partene synes dermed å være hørt gjennom FRHO. Det andre unntaket er ambulansefaget, som FROH foreslår som et femårig løp.

Arbeidsutvalget i FRHO består av representanter fra Utdanningsforbundet (lærer), Fagforbundet (sosiolog) og arbeidsgiver (sykepleier), og representerer dermed ikke de yrkesfagene rådet skal ivareta gjennom egen fagbakgrunn. FRHO har derfor hatt mange dialogmøter, med bransjene involvert, for å få innspill. De opplever at de jobber i nær dialog med de som sitter ute i bransjene og at de derfor ivaretar de ulike fagenes interesser. FRHO har noen utfordringer knyttet til grenseoppgang mellom Utdanningsdirektoratets og rådets arbeid og ansvar. Alle opplever at partene blir hørt og har nødvendig innflytelse. Bortsett fra når det gjelder ambulansefaget, så er forslaget fra faglig råd likt den endelige strukturen. FRHO har foreslått at ambulansefaget skal bli femårig, mens KD lar det ligge som før i strukturen - inntil videre.

FRHOs opplevelse av å ha innflytelse er i tråd med resultatet av endringsprosessen, som viser at FRHOs forslag er identisk med den endelige strukturen som er vedtatt av KD. Her hadde 
Utdanningsdirektoratet et annet forslag angående hudpleiefaget, som ikke var i tråd med hverken FRHOs forslag eller det endelige vedtaket. Å flytte aktivitør til HO, gjør utdanningsprogrammet bredere med et nytt fag. Dette kan gjøre utfordringer knyttet til relevans og konsistens større. Endringen har ikke betydning for utdanningsprogrammets bærekraftighet.

\section{ENDRINGER I STRUKTUREN, UTDANNINGSPROGRAM RESTAURANT- OG MATFAG (RM)}

Figuren nedenfor viser analyseresultatet av endringsprosessen mot fastsatt struktur i utdanningsprogram Restaurant- og matfag (RM).

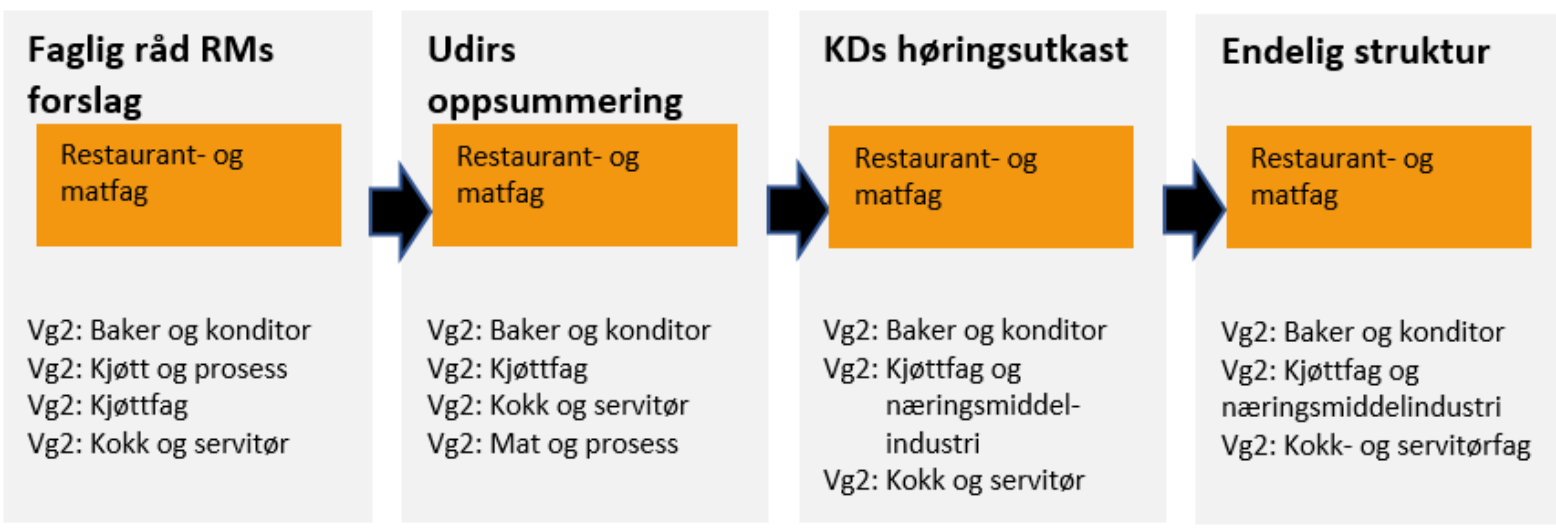

\section{Figur 8}

Viser beslutningsprosessen mot fastsatt struktur i utdanningsprogram Restaurant- og matfag (RM).

Når det gjelder utdanningsprogram for Restaurant- og matfag, er faglig råd (FRRM), Udir og KD i all hovedsak enige om å beholde Vg1 som i dag og å dele matfagene i flere mindre Vg2. Faglig råd foreslår å dele matfagene i tre, noe Udir støtter, mens KD foreslår og vedtar å dele det i to. Lærefagene i de nye Vg2 får mer til felles, og relevans og konsistens bør derfor kunne ivaretas. Bærekraft og distriktspolitiske utfordringer kan diskuteres, da de to Vg2tilbudene blir forholdsvis små og smale.

Representanter fra Faglig råd for RM uttrykker i intervjuet sin mening om at trepartssamarbeidet generelt er under press. De har slitt lenge med forholdet til direktoratet og til KD for å bli hørt og bli tatt på alvor slik de mener ILO-konvensjonen skal tolkes. I rådet er det ingen konflikter knyttet til at man kommer fra ulike parter. KS sine representanter "sitter hos oss med 2 hatter på, både som arbeidsgiver og som skoleeier ... “. Rådet mangler fagkompetanse på slakterfaget og konditorfaget av de 12 lærefagene. Alle i arbeidsutvalget har fagbrev. Rådet har et prinsippvedtak på at faglige råd skal ha all makt og innflytelse på fag- og yrkesopplæringen. "Hvem andre enn arbeidslivets parter og skolene, lærerne, skal 
bestemme hvordan fag- og yrkesutdanningen skal se ut? Vi burde ha vedtaksrett på dette området der".

FRRM har slitt med å ha tilstrekkelig innflytelse både i Utdanningsdirektoratet og i KD. I denne endringsprosessen har Utdanningsdirektoratet hørt på FRRM og støttet deres forslag om struktur, mens KD har vedtatt et annet forslag. I den endelige strukturen er kjøttfag og næringsmiddelindustri slått sammen til ett $\mathrm{Vg} 2$, i strid med FRRM og Udir sitt forslag.

Utfordringer knyttet til relevans og konsistens blir som før i Vg1, men mindre i Vg2, da disse er gjort smalere. De smalere Vg2 kan samtidig gjøre strukturen mindre bærekraftig, da det vil være vanskelig å fylle klasser utover landet.

\section{ENDRINGER I STRUKTUREN, UTDANNINGSPROGRAM SERVICE OG SAMFERDSEL (SS)}

Figuren nedenfor viser analyseresultatet av endringsprosessen mot fastsatt struktur i utdanningsprogram Service og samferdsel (SS).

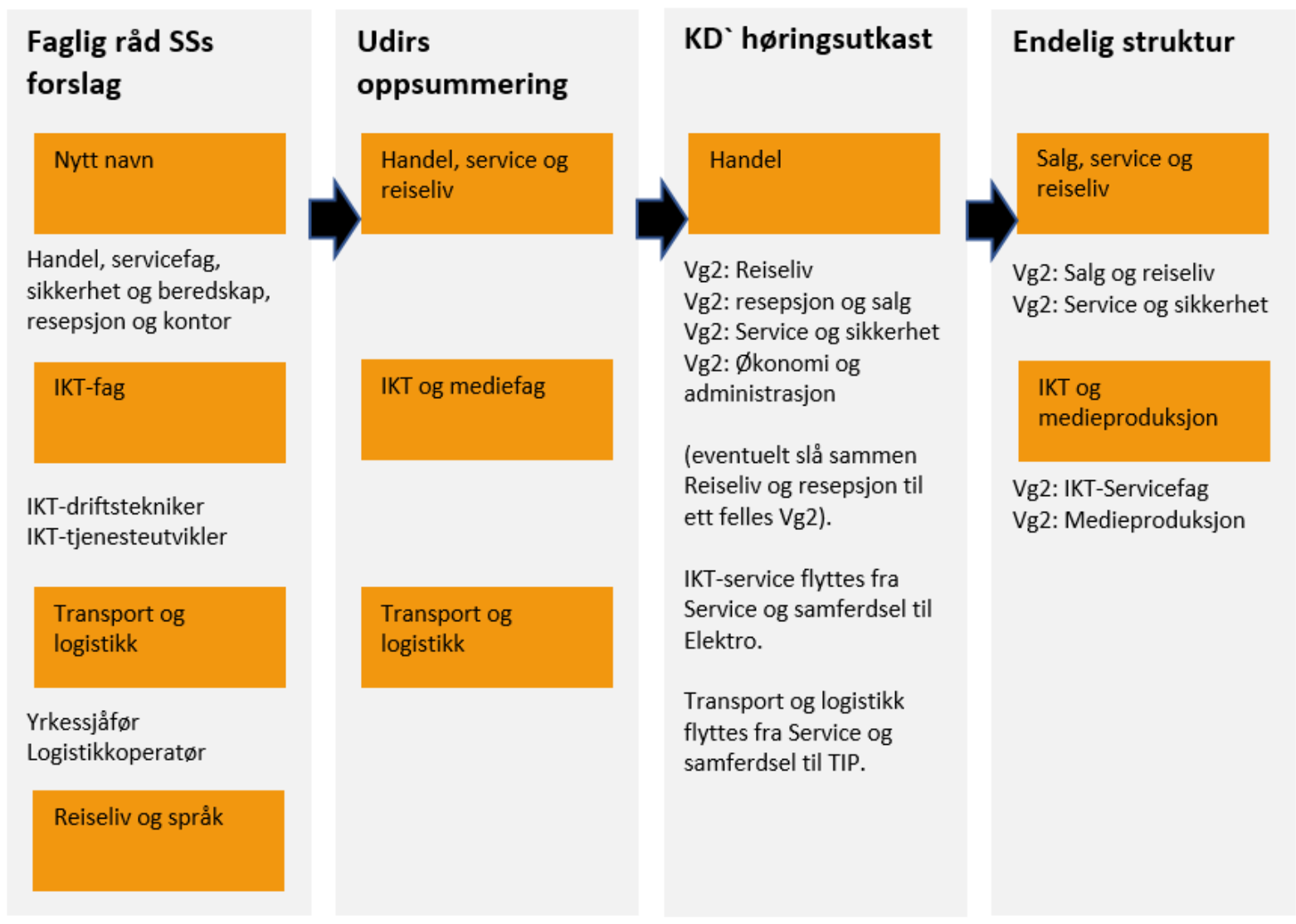

\section{Figur 9}

Viser beslutningsprosessen mot fastsatt struktur i utdanningsprogram Service og samferdsel (SS) 
Faglig råd for Service og samferdsel (FRSS) foreslår å dele dagens Vg1 i fire nye. Udir foreslår tre og KD ett i sitt høringsutkast. I den endelige strukturen har KD vedtatt to nye Vg1 og at Transport- og logistikkfaget flyttes til utdanningsprogram for Teknikk og industriell produksjon (TIP). FRSS har ikke blitt hørt i stor grad, noe som kan ha å gjøre med manglende bærekraft i forslaget. Forslaget om et eget utdanningsprogram for IKT og medieproduksjon ligger i utviklingsredegjørelsen fra Faglig råd for Medier og kommunikasjon (FRMK) og i forslaget til struktur fra Udir. Det betyr at FRSS ikke har hatt innflytelse, i motsetning til FRMK, når det gjelder det nye utdanningsprogrammet IKT og medieproduksjon.

Det faglige rådet i SS var sammensatt av personer med bakgrunn fra LO og NHO. Fagbakgrunnen til de to personene fra arbeidsutvalget var en med kontorfaglig utdanning og den andre med master i internasjonal utdanning. Noen fag får mer oppmerksomhet enn andre i rådet. Det er mangelfull representasjon fra endel fagfelt som IKT og logistikk. Flere av medlemmene er ansatt i organisasjonene. det kom fram i ett av intervjuene at: ... det som er spesielt for service/samferdsel det er jo det som vi frontet i år som hybrid, altså det der med hybrid modell, vi er hverken det ene eller det andre. Så det er litt den nye generasjonen av yrkesfag da. En del av fagene våre har store utfordringer med å bli verdsatt $\mathrm{i}$ arbeidslivet. Andre fag er en start på videreutdanning for å kunne bli ansatt. Vi ser jo at mange av våre fag har store utfordringer i forhold til å bli anerkjent og verdsatt i arbeidslivet. Og det er klart at vi i den forbindelse også ser på andre måter å strukturere fagene på for å si det sånn. (Et medlem av faglig råd $\mathrm{SS}$ ).

I denne endringsprosessen har FRSS foreslått en annen løsning enn både Utdanningsdirektoratet og den endelige strukturen som er vedtatt av KD og har dermed ikke nådd fram med sitt forslag. Utfordringer knyttet til konsistens og relevans blir enklere å håndtere, da Vg1 blir smalere, mens om dette ikke synes å være et tiltak som fremmer bærekraft. Vg1 Salg, service og reiseliv vil kanskje fremdeles være så stort at det vil kunne finnes over hele landet og vil på den måten være bærekraftig. Omfanget av det nye utdanningsprogrammet IKT og medieproduksjon og behovet for lærefagene i utdanningsprogrammet vet vi lite om med tanke på utdanningsprogrammets bærekraft. Relevans og konsistens synes å være ivaretatt, da fagene ifølge fagmiljøene har mye til felles. 


\section{UTDANNINGSPROGRAM TEKNIKK OG INDUSTRIELL PRODUKSJON (TIP)}

Figuren nedenfor viser analyseresultatet av endringsprosessen mot fastsatt struktur i utdanningsprogram Teknikk og industriell produksjon (TIP).

\begin{tabular}{|c|c|c|c|}
\hline $\begin{array}{l}\text { Faglig råd TIPs } \\
\text { forslag }\end{array}$ & $\begin{array}{l}\text { Udirs } \\
\text { oppsummering }\end{array}$ & KDs høringsutkast & Endelig struktur \\
\hline $\begin{array}{l}\text { Teknikk og } \\
\text { industriell } \\
\text { produksjon }\end{array}$ & $\begin{array}{l}\text { Teknikk og } \\
\text { industriell } \\
\text { produksjon }\end{array}$ & $\begin{array}{l}\text { Teknikk og } \\
\text { industriell } \\
\text { produksjon }\end{array}$ & $\begin{array}{l}\text { Teknikk og } \\
\text { industriell } \\
\text { produksjon }\end{array}$ \\
\hline $\begin{array}{l}\text { Vg2: Arbeidsmaskiner } \\
\text { Vg2: Bilskade, lakk og } \\
\quad \text { karosseri } \\
\text { Vg2: Brønnteknikk } \\
\text { Vg2: Kjemiprosess- og } \\
\quad \text { laboratoriefag } \\
\text { Vg2: Kjøretøy } \\
\text { Vg2: Maritime fag } \\
\text { Vg2: Industriteknologi } \\
\text { Flere av de små og smale } \\
\text { lærefagene legges ned } \\
\text { eller slås sammen. } \\
\text { Låsesmedfaget legges til } \\
\text { Elektro } \\
\text { Endring av } \\
\text { motorsykkelfaget til el-og } \\
\text { motorsykkelfaget }\end{array}$ & $\begin{array}{l}\text { Vg2: Arbeidsmaskiner } \\
\text { Vg2: Bilskade, lakk og } \\
\text { karosseri } \\
\text { Vg2: Brønnteknikk } \\
\text { Vg2: Kjemiprosess- og } \\
\text { laboratoriefag } \\
\text { Vg2: Kjøretøy } \\
\text { Vg2: Maritime fag } \\
\text { Vg2: Industriteknologi } \\
\text { Legges ned: } \\
\text { Vg2: Industriell } \\
\text { møbelproduksjon } \\
\text { Vg2: Industritekstil og } \\
\text { design } \\
\text { Vg3: } \\
\text { Chassispåbyggerfaget blir } \\
\text { en del av Vg3 } \\
\text { Industrimekanikerfaget } \\
\text { som valgbar fordypning } \\
\text { Kran- og } \\
\text { løfteoperasjonsfaget } \\
\text { flyttes til Vg2 Transport } \\
\text { og logistikk }\end{array}$ & $\begin{array}{l}\text { Vg2: Arbeidsmaskiner } \\
\text { Vg2: Bilskade, lakk og } \\
\text { karosseri } \\
\text { Vg2: Brønnteknikk } \\
\text { Vg2: Kjemiprosess- og } \\
\text { laboratoriefag } \\
\text { Vg2: Kjøretøy } \\
\text { Vg2: Maritime fag } \\
\text { Vg2: Industriteknologi } \\
\text { Vg2: Transport og } \\
\text { logistikk (fra SS) } \\
\\
\text { Flere av de små og smale } \\
\text { lærefagene legges ned } \\
\text { eller slås sammen. }\end{array}$ & $\begin{array}{l}\text { Vg2: Arbeidsmaskiner } \\
\text { Vg2: Bilskade, lakk og } \\
\text { karosseri } \\
\text { Vg2: Brønnteknikk } \\
\text { Vg2: Kjemiprosess- og } \\
\quad \text { laboratoriefag } \\
\text { Vg2: Kjøretøy } \\
\text { Vg2: Maritime fag } \\
\text { Vg2: Industriteknologi } \\
\text { Vg2: Transport og } \\
\text { logistikk } \\
\text { Vg2 Treteknikk er lagt til } \\
\text { BA }\end{array}$ \\
\hline
\end{tabular}

\section{Figur 10}

Viser beslutningsprosessen mot fastsatt struktur i utdanningsprogram Teknikk og industriell produksjon (TIP)

I Utdanningsprogram for TIP er Faglig råd (FRTIP), Udir og KD enige om å legge ned mange av de små lærefagene og at det skal være ett Vg1 som i dag. Unntaket er transport- og logistikkfagene, som av KD foreslås og vedtas lagt til TIP fra SS. De velger da en løsning som gir større utfordring knyttet til å oppnå yrkesrelevans og konsistens, da lærefagene blir enda mer forskjellige i utdanningsprogrammet enn i dag. Bærekraften kan bli bedre da de små fagene legges ned, og det er flere læreplasser i de lærefagene som gjenstår.

I intervju med faglig råd for TIP kom det frem at rådet var sammensatt av personer fra organisasjonene hvor noen er ansatt i organisasjonene og andre med fagtilhørighet $\mathrm{i}$ yrket fra bil, gass, olje og sjøfart. Arbeidsutvalget består av en lærer i yrket og to ansatte fra Norsk 
Industri og Fellesforbundet. Det er ikke et ønske å få et bredere Vg1-løp, men en gjennomgang av Vg1 og Vg2 for å kunne ivareta fag som prosess og særløpsfag. Rådet mener de har for liten innflytelse i forhold til avgjørelser som blir tatt i Utdanningsdirektorat og departement. De opplever at deres råd ikke nødvendigvis blir hørt og fulgt. AU opplever at utdanningsprogrammet er bredt nok. De mener at det kanskje kan være behov for deling av Vg2 Industriteknologi (IT).

FRTIP har ikke nådd fram med sitt forslag til struktur på flere områder. Dette er i tråd med deres generelle opplevelse av ikke å ha innflytelse hos Udir og KD i mange sammenhenger. FRTIP $\varnothing$ nsket et smalere utdanningsprogram, men resultatet viser at de heller er blitt bredere. Transport- og logistikkfagene er på mange måter svært ulike de lærefagene som i dag inngår i utdanningsprogrammet, og kan gjøre utfordringene med å oppnå relevans og konsistens i tråd med føringene fra KD enda større enn i dag. FRTIP ønsket også en oppdeling av Vg2 Industriteknologi, som i dag omfatter 24 lærefag. I den vedtatte strukturen er Vg2 Industriteknologi blitt enda bredere og omfatter nå 29 lærefag. Da utdanningsprogrammet har blitt bredere synes utfordringene knyttet til relevans og konsistens å ha blitt større. På grunn av bredden i Vg1 vil det være mulig å tilby TIP over hele landet. Det kan ivareta føringene om bærekraft.

\section{Oppsummering av de faglige rådenes innflytelse}

Kort oppsummert viser resultatene og analysen at det er stor forskjell på hvordan de faglige rådene når fram med sine forslag og synspunkter. Tabellen nedenfor viser hvilke faglige råd som har nådd fram med sine forslag hos Utdanningsdirektoratet og videre hos Kunnskapsdepartementet. Tabellen viser også hvordan de faglige rådene generelt sett erfarer å bli hørt og å ha innflytelse. 


\section{Tabell 1}

Hvordan de faglige rådene blir hørt, og hvordan de opplever å bli hørt, av

Utdanningsdirektoratet og Kunnskapsdepartementet forklares i teksten.

\begin{tabular}{|c|c|c|c|}
\hline $\begin{array}{l}\text { Faglige } \\
\text { råd }\end{array}$ & $\begin{array}{l}\text { Hørt av } \\
\text { Udir. }\end{array}$ & $\begin{array}{l}\text { Hørt av KD } \\
\text { (forslag) }\end{array}$ & Opplever å bli hørt av Udir og KD? \\
\hline BA & $\mathrm{Ja}$ & $\mathrm{Ja}$ & Opplever å jobbe hardt for å få innflytelse \\
\hline DH & nei & nei & Opplever å bli hørt, men blir det ikke \\
\hline EL & $\mathrm{Ja}$ & $\begin{array}{l}\text { Delvis } \\
\text { (i hovedsak. Unntak } \\
\text { navnet og hybridmodeller) }\end{array}$ & $\begin{array}{l}\text { Opplever delvis å bli hørt, men } \emptyset \text { nsker avgjørende } \\
\text { innflytelse ikke bare rådgivende. Kritisk til manglende } \\
\text { involvering i starten av endringsarbeidet }\end{array}$ \\
\hline $\mathrm{HO}$ & $\begin{array}{l}\text { Delvis } \\
(- \\
\text { hudpleie })\end{array}$ & $\mathrm{Ja}$ & Opplever å bli hørt og å ha nødvendig innflytelse \\
\hline MK & $\mathrm{Ja}$ & $\begin{array}{l}\text { ja IKT og mediefag var } \\
\text { foreslått av Udir, og ble } \\
\text { etter høring vedtatt av KD }\end{array}$ & Ble ikke intervjuet (slått sammen med DH) \\
\hline RM & $\mathrm{Ja}$ & $\begin{array}{l}\text { Delvis (KD gikk for } 3 \mathrm{i} \\
\text { stedet for } 4 \mathrm{Vg} 2 \text { ) }\end{array}$ & $\begin{array}{l}\text { Opplever at de sliter med å bli hørt og tatt på alvor i } \\
\text { forhold til tolkning av ILO-konvensjonen. Opplever at } \\
\text { trepartssamarbeidet er under press. }\end{array}$ \\
\hline SS & Nei & Nei & $\begin{array}{l}\text { De opplevde det som vanskelig å komme med forslag, } \\
\text { da rådet mangler representasjon på en del fagfelt (IKT } \\
\text { og logistikk), at yrkesfagene i utdanningsprogrammet } \\
\text { er nye og sliter med anerkjennelse i arbeidslivet. }\end{array}$ \\
\hline TIP & nei & nei & Opplever ikke å bli hørt. \\
\hline & \multicolumn{2}{|c|}{$\begin{array}{l}\text { Enige om nedlegging av mange små } \\
\text { fag. De ønsket ikke å bli bredere på } \\
\text { Vg1, men har blitt det med tillegg av } \\
\text { yrkessjåfør og logistikk. }\end{array}$} & \\
\hline
\end{tabular}

De faglige rådene som har fått gjennom sine forslag, er FRBA, FREL og FRRM. Alle disse faglige rådene ønsker samtidig mer innflytelse og å bli hørt i større grad.

FRTIP fikk ikke gjennomslag for sitt forslag, da Vg1 ble utvidet med blant annet logistikkog yrkessjåførfagene, som er svært annerledes enn de andre yrkesfagene i TIP og dermed et avvik fra kriteriene om relevans og konsistens i yrkesopplæringen.

FRDH og FRHO opplever generelt sett at de blir hørt og at de har tilstrekkelig innflytelse.

Samtidig har FRDH i denne endringsprosessen ikke nådd fram med sitt forslag, mens FRHO har nådd fram med sitt. FRDH foreslo at DH skulle deles inn i fem $\mathrm{Vg} 1$, mens Udir foreslo fire og KD foreslo to, som ble resultatet. Begrunnelsen for at FRDH (og Udir) ikke fikk gjennomslag, kan forklares med at forslagene ikke ivaretar KDs kriterier for bærekraft. 
Utdanningsprogrammene ville ha blitt så små at et tilbud for alle unge i hele landet ville vært vanskelig å få til.

Faglig råd for utdanningsprogrammet Medier og kommunikasjon (FRMK) ble ikke intervjuet, da utdanningsprogrammene Medier og Kommunikasjon (MK) var slått sammen med utdanningsprogrammet Design og Håndverk (DH). De hadde likevel foreslått, etter hvert i samarbeid med FRSS, et eget Vg1 for IKT og mediefag.

FRSS fikk ikke gjennomslag for sitt forslag om å dele SS i fire Vg1, men støttet etter hvert, etter at deres forslag var sendt til Udir, et forslag fra FRMK om et eget Vg1 for IKT og mediefag.

Forhold som kan ha hatt betydning for hvordan de enkelte rådene har nådd fram med sine forslag, kan blant annet være at Kunnskapsdepartementets kriterier for endringene ikke var klare da rådene utformet sine forslag til struktur. Dette gjelder spesielt kriteriet som handler om bærekraft og ungdommers muligheter for å ta fagopplæring i hele landet.

\section{Drøfting av funn}

Funnene drøftes i forhold til teori knyttet til makt og innflytelse i strukturendringsprosessen. Maktens former er mangefasetterte. I denne artikkelen berøres bare en liten del og omhandler de nasjonale føringene og hvilken innflytelse og makt fagmiljøene og bransjene har i endringsprosessen, gjennom trepartssamarbeidet. Perspektivene i drøftingen har fokus på politisk og ideologisk makt og formes i et samspill mellom strukturelle rammer og tilsiktet handling, mellom det ugjennomsiktige og det erkjente, og det er glidende overganger mellom disse (NOU 2003:19, s. 12). Tilslutt gjør vi en sammenfattende drøfting knyttet til problemstillingen og forskningsspørsmålet.

\section{Politisk makt}

I problemstillingen stiller vi spørsmålet om på hvilken måte fagmiljøene og bransjene gjennom trepartssamarbeidet har innflytelse over strukturendringene i norsk yrkesopplæring? Denne studien viser at nasjonale myndigheter delvis går utenfor det formelle trepartssamarbeidet i beslutningsprosessen, som vist i figur 3. Dette kan ha betydning for fagmiljøenes muligheter for innflytelse, hvordan ideologien bak utdanningspolitikken og kvaliteten i yrkesopplæringen ivaretas. De regjeringsoppnevnte yrkesfaglige utvalgene ble opprettet på siden av den formelle beslutningsprosessen. Utvalgene var ikke partssammensatt 
eller hadde medlemmer som representerte fagmiljøene, og de ble involvert i endringsarbeidet parallelt med at de faglige rådene fikk i oppdrag å uttale seg om verdsetting av de ulike yrkesfagene i samfunnet, samt et eventuelt behov for endring av yrkesopplæringens struktur. Regjeringen begrunnet oppnevning av utvalgene med at de ville sikre en bred involvering av aktører som til vanlig ikke er involvert i fag- og yrkesopplæringen. Etter press fra partene i prosessen ble resultatet av arbeidet i de yrkesfaglige utvalgene delt med de faglige rådene, før rådene leverte sine forslag til struktur (Hasås, 2017).

Ikke alle fagmiljøer er representert i dagens faglige råd. Det betyr at de fagmiljøene som ikke er representert kan ha mindre innflytelse enn de er tenkt å ha i henhold til ILO-konvensjonen. Manglende representasjon fra fagmiljøene kan også være en viktig faktor i den forskyvningen av makt over faglig utvikling mot statlig styring, som funnene i denne studien viser. Så tidlig som i 2008 meldte Olsen sin bekymring over at norsk fag- og yrkesopplæring var på vei til å bli et statlig regulert utdanningssystem (Olsen, 2008). Bakgrunnen for hans bekymring var blant annet de nasjonale institusjonelle endringene i partssamarbeidet, som førte til at de faglige rådene og rådsmedlemmene ikke lenger representerte fagenes spesifikke faglighet, men den mer generelle konteksten fagene inngår i (Olsen, 2008). Våre funn viser at fagmiljøene ikke nødvendigvis er involvert og har innflytelse over strukturendringer som kan ha betydning for den faglige kvaliteten i yrkesopplæringen. Distansen mellom arbeidslivets representanter for de ulike yrkesfagene og de faglige rådene har blitt større for mange yrkesfag og de faglige rådenes sekretariat ligger i Utdanningsdirektoratet. Tidligere var disse gjerne lagt til et fagforbund eller en bransjeorganisasjon der ett eller flere av rådsmedlemmene hadde sitt arbeid (Olsen, 2008). I samsvar med Olsen (2008; 2011), synes det også som om de faglige rådenes reelle posisjon er snevret inn, at det har foregått ei maktforskyvning også når det gjelder fagenes innflytelse på fagutviklingen i egne fag. Denne studien viser at fagmiljøenes og bransjenes muligheter for innflytelse svekkes, noe som kan utfordre fagligheten i endringsarbeidet. Demokratiet i fagopplæringen utfordres, samtidig som vektlegging av kvalitet i yrkesopplæringen står i fare for å reduseres, gjennom fagenes manglende involvering og innflytelse.

Vi undres på om vi allerede ser resultater av det Høst (2015a) problematiserer i sin rapport, at dersom den statlige involveringen blir for sterk, vil dette kunne føre til at lærebedriftene drives ut av fagopplæringen. I dag står flere tusen elever i Norge på venteliste til en lærlingeplass, noe som ikke er i tråd med KDs mål om bærekraftig yrkesopplæring og læreplass til alle som $\varnothing$ nsker det. Disse elevene har avsluttet to år av sin yrkesfaglige 
utdanning i skole og venter på å få fullføre utdanningen som lærlinger i bedrift. Kan lærebedriftene i større grad utfordres til å ta ansvar for utdanning av morgendagens fagarbeidere, eller må dimensjoneringen i større grad tilpasses det antall læreplasser arbeidslivet kan tilby, for at KD sitt mål om bærekraftig yrkesutdanning skal oppnås (Høst mfl., 2015b; Olsen, 2008; 2011).

En vurdering, som i liten grad er belyst godt i kunnskapsgrunnlaget for endringsprosessen eller i beslutningsprosessen, er hvilke konsekvenser endringene i struktur kan få for elever og fylkeskommuner. Da tenker vi for eksempel på elevenes tilgang til utdanning i tråd med deres førstevalg, og om fylkeskommunene må endre sine tilbud basert på ny struktur.

Etter at strukturen nå er fastsatt av KD, er et nytt ikke-partssammensatt utvalg oppnevnt, Liedutvalget, som skal se på strukturen i hele den videregående opplæringen. Dette utvalget har heller ikke representasjon fra fagmiljøene med tilhørende bransjer og er kanskje er et nytt eksempel på fagmiljøenes og trepartssamarbeidets manglende innflytelse på endringer i yrkesopplæringen.

\section{Ideologisk makt}

Ideologiske makt er ifølge Fredrik Engelstad (2016) den makt som er koblet opp mot ideer og kultur i vid forstand (2016, s.126). Ideologisk makt har innflytelse både på politisk og økonomisk makt. (NOU 2003:19, s.11). Formelt sett skal partene ha stor ideologisk makt og innflytelse på endringer i yrkesopplæringen. De skal bidra med faglig kompetanse og kunnskap om behov som fagene og bransjene har (ILO-konvensjonen, 2018), og bidra til at den enkelte, virksomhetene og samfunnet får den kompetansen de har behov for. Resultater i denne studien viser at de faglige rådene reelt sett har ulik faglig innflytelse. I tillegg til at de har mistet beslutningsmyndighet i mange saker og formelt sett kun har en rådgivende funksjon har de ulik grad innflytelse på beslutningene i denne endringsprosessen.

Oppsummeringen av i hvilken grad de faglige rådene har nådd fram med sine forslag, viser at ca. halvparten ble hørt og halvparten ikke. I løpet av strukturendringsprosessen ble begrepene bærekraft, relevans og konsistens lansert av KD som bærende prinsipper og grunnlag for endringsprosessen. Når det gjelder kriteriet om bærekraft, så inneholder dette, i tillegg til en dimensjonering og tilpasning til bransjenes og samfunnets behov, en distriktspolitisk føring om at strukturen skal gi et godt grunnlag for fagopplæring i hele landet. Det betyr at utdanningsprogrammene må ha elevgrunnlag og lærlingebedrifter for å kunne opprettes i alle landets fylker. I dette perspektivet kan det stilles spørsmål ved beslutningen om oppretting av 
et eget Vg1 for IKT og medieproduksjon, hvor rekrutteringsgrunnlaget er usikkert og kan være tynt i de små fylkene og byene. Samtidig var KD opptatt av prinsippet om relevans, at fagene som er sammen på $\mathrm{Vg} 1$ og i brede $\mathrm{Vg} 2$, må ha så mye til felles at det er mulig å ivareta de ulike yrkenes kompetansebehov. KD har i forhold til dette kriteriet ikke vært konsekvent i sine beslutninger. De har besluttet smalere Vg1 og Vg2 i tråd med forslag fra de faglige rådene, bortsett fra på TIP, hvor de i praksis har laget et bredere Vg1. To store og svært forskjellige fagområder fra Service og samferdsel; logistikk og yrkessjåfør, er flyttet til TIP, som dermed reelt sett har blitt bredere, selv om små lærefag samtidig har blitt nedlagt eller slått sammen med andre fag. Når det gjelder KDs kriteriene om konsistens og relevans i opplæringsløpet fra Vg1 til Vg3, synes dette fremdeles å være utfordrende på grunn av den store bredden i Vg1 og Vg2 Industriteknikk.

Som vist i tabell nr. 1, fikk de faglige rådene i ulik grad gjennomslag for sine forslag til endringer. Dette kan ha flere årsaker. Det kan blant annet ha sammenheng med at forslagene ikke samsvarte med KDs kriterier som ble lansert underveis i prosessen. Det synes som om kriteriene ikke ble presentert på en tydelig måte, eller var uklare i Utdanningsdirektoratets oppdrag til de faglige rådene på det tidspunktet de leverte sine forslag til struktur. De faglige rådene kan ha forholdt seg til de rent faglige utfordringene, mens KD i sine kriterier forutsatte en annen helhetlig vurdering som blant annet innbefattet distriktspolitiske hensyn. Dette kan være en aktuell årsak til at rådene hadde ulik innflytelse.

Det er gjennom de faglige rådene de enkelte fagmiljøene kan bli hørt. Fagarbeidere i dagens arbeidsliv er i liten grad eller tilfeldig involvert i endringsarbeidet, og det er ulikt hvor mye fagene er representert i de faglige rådene, noe som i FRSS opplevdes som vanskelig når de skulle foreslå ny struktur. Manglende faglig representasjon kan resultere i at faglige beslutninger blir tatt uten at fagmiljøene og bransjene er involvert. Dette kan resultere i at kvalitet i yrkesopplæringen og på faglig arbeid utfordres og at fagutviklingen i disse fagene bestemmes av byråkrater og nasjonale myndigheter.

\section{Økonomisk makt}

I forbindelse med innføring av rett til treårig utdanning for alle elever gjennom Reform 94, forutsatte partene at staten skulle bære en del av kostnadene til bedriftsopplæringen gjennom $\varnothing k t$ lærlingtilskudd (Nyen \& Hagen Tøndel, 2014, s.76; Høst, 2015a). Dette kan være en medvirkende årsak til at staten ønsker mer innflytelse og kontroll på innhold og struktur i 
yrkesopplæringen. De ønsker med andre ord mer politisk og økonomisk makt, mens den ideologiske makten som fagmiljøene har hatt tidligere, derfor må vike (Sund, 2005).

\section{Drøfting i forhold til problemstillingen}

I problemstillingen spør vi om på hvilken måte fagmiljøene og bransjene har innflytelse på endringene i struktur som gjфres i norsk yrkesopplaring. KDs beslutningsprosedyrer synes å variere, samt ikke å følge de prosedyrer partene har blitt enige om for å ivareta innholdet i ILO-konvensjonen. Bransjenes og fagmiljøenes faglige og ideologiske innflytelse synes å reduseres noe til fordel for en sterkere statlig styring gjennom politisk ledelse i Kunnskapsdepartementet. KD synes å ta sine beslutninger delvis utenom partssystemet og fagmiljøenes innflytelse synes å være tilfeldige. KD går ut i andre miljøer gjennom de regjeringsoppnevnte yrkesfaglige utvalgene for å utvikle den kunnskapen de vil legge til grunn for beslutningene. Dette svekker nærheten til og involvering av fagmiljøene. Det kan diskuteres i hvor stor grad fagene/fagmiljøene involveres gjennom de faglige rådene, da medlemmene ikke nødvendigvis har fagkompetanse innen de yrkesfagene de representerer og det ikke finnes noe formelt system for involvering av fagkompetanse som grunnlag for råd til KD i faglige saker. Det er for eksempel opp til hvert enkelt faglige råd eventuelt å involvere fagmiljøene innenfor sine budsjetter.

Forskningsspørsmålet handler om hvilken innflytelse fagmiljøene har gjennom trepartssamarbeidet $i$ de nasjonale faglige rådene? Partene synes å ha gode faglige samtaler i de faglige rådene og at det er stor grad av enighet mellom partene rundt faglige spørsmål. Det er kanskje da spesielt interessant at halvparten av rådene ikke har fått gjennomslag i Udir og KD med sine forslag. Olsen (2008) stilte spørsmål i et notat om de institusjonelle endringsprosesser som trådte i kraft i norsk fag- og yrkesutdanning i 2008, ville føre til fornyelse eller gradvis omdannelse av trepartssamarbeidet.

Denne studien viser at byråkratiet i regi av Utdanningsdirektoratet og Kunnskapsdepartementet har stor makt over både politisk bestemte endringsprosesser og over den ideologien som ligger til grunn for yrkesopplæringen. Deler av fagmiljøene og partssamarbeidet har liten og lite systematisk innflytelse på endringsprosessene. En maktforskyvning fra fag og partene i arbeidslivet til statlig styring har, også i følge Nyen og Tøndel (2014), vært tydelig fra 1994 og fram til i dag.

Funnene i denne studien viser at både den politiske og den ideologiske makten er svekket til fordel for større makt i stat og byråkrati. Vi kan dermed stille spørsmålstegn ved hvordan 
fagligheten i yrkesopplæringen ivaretas og kvalitetssikres i endringsprosessen mot ny fagopplæring gjennom trepartssamarbeidet i de faglige rådene.

\section{Litteraturliste}

Andersen, R. K. \& Andresen, S. (2016a). Rekruttering, frafall og overgang til laereplass på restaurant- og matfag. Fafo-rapport 2016:09. Lastet ned 12.09. 2019 fra: https://www.fafo.no/index.php/zoo-publikasjoner/fafo-rapporter/item/rekrutteringfrafall-og-overgang-til-laereplass-pa-restaurant-og-matfag

Charmaz, K. (2006). Constructing Grounded Theory: a practical guide through qualitative analysis. London: Sage.

Deichman-Sørensen T. (2015). «Lik kvalitet»-fra yrkesstyring til ytrestyring, fra praksisfelleskap til fellesmarked. Framveksten av en ny kvalitetsфkonomi i fag-og yrkesopplacingen. I: O. Eikeland; H. Hiim \& E. Schwencke (red.) Yrkespedagogiske perspektiver (s. 219-270). Oslo: Gyldendal Akademisk.

Engelstad, F. (2016). Hva er makt? (4. opplag). Oslo: Universitetsforlaget

Faglig råd for Bygg- og anleggsteknikk (2016). Utviklingsredegjørelse - del 2. Lastet ned 12.09.2019 fra:

https://www.udir.no/globalassets/upload/faglig_rad/utviklingsredegj_del-2-frba.pdf

Faglig råd for Design og håndverk (2016). Utviklingsredegjørelse - del 2. Lastet ned 12.09.2019 fra:

https://www.udir.no/globalassets/filer/samlesider/fagopplaring/tilbudsstruktur/fagligrad-for-design-og-handverk.pdf

Faglig råd for Elektro (2016). Utviklingsredegjørelse - del 2. Lastet ned 12.09.2019 fra:.

https://www.udir.no/globalassets/filer/samlesider/fagopplaring/tilbudsstruktur/fagligerad-for-elektro.pdf

Faglig råd for Helse- og oppvekstfag (2016). Utviklingsredegjørelse - del 2. Lastet ned 12.09.2019 fra:

https://www.udir.no/globalassets/filer/samlesider/fagopplaring/tilbudsstruktur/fagligrad-for-helse--og-oppvekstfag.pdf 
Faglig råd for Restaurant- og matfag (2016). Utviklingsredegjørelse - del 2. Lastet ned 12.09.2019 fra:

https://www.udir.no/globalassets/filer/samlesider/fagopplaring/tilbudsstruktur/fagligrad-for-restaurant--og-matfag.pdf

Faglig råd for Service og samferdsel (2016). Utviklingsredegjфrelse - del 2. Lastet ned 12.09.2019 fra:

https://www.udir.no/globalassets/filer/samlesider/fagopplaring/tilbudsstruktur/fagligrad-for-service-og-samferdsel.pdf

Faglig råd for Teknikk og industriell produksjon (2016). Utviklingsredegjørelse - del 2.

Lastet ned 12.09.2019 fra:

https://www.udir.no/globalassets/filer/samlesider/fagopplaring/tilbudsstruktur/fagligrad-for-teknikk-og-industriell-produksjon.pdf

FN-sambandet. United Nations Association of Norway (1975). ILO 142. Geneva: FNsambandet

Grønmo, S. (2015). Samfunnsvitenskapelige metoder. Bergen: Fagbokforlaget

Hagen Tøndel A. \& Skinnarland, S. (2016). Rekruttering til design- og håndverksfagene. Fafo-rapport 2016:10. lastet ned 30.06.2018 fra:

https://www.udir.no/globalassets/filer/tall-og-

forskning/forskningsrapporter/rekruttering-til-design--og-handverksfagene-faforapport-mars-2016.pdf

Hasås, Torgny (2017) Nytt utvalg overrasker Fagopplaerings-Norge. FriFagbevegelse Lastet ned 20.03. 2018 fra: https://frifagbevegelse.no/i-skolen/nytt-utvalg-overraskerfagopplaringsnorge-6.158.485309.385d5c9ede

Høst, H. (red.) (2015a). Kvalitet i fag- og yrkesopplæringen. NIFU - rapport. Sluttrapport. Lastet ned 28.09.2019 fra: http://hdl.handle.net/11250/284140

Høst, H., Reegård, K., Borgan, R. R., Skålholt, A. \& Hagen Tøndel, A. (2015b).

Yrkesutdanninger med svak forankring i arbeidslivet: En kunnskapsoppsummering. NIFU-rapport 2015:16 Lastet ned 3.10.2019 fra: https://www.nifu.no/publications/1244676/ 
ILO - konvensjoner (2018). Lastet ned 20.03.2018 fra: https://www.fn.no/Om$\underline{\text { FN/Avtaler/Arbeidsliv/ILO-konvensjoner }}$

Johannessen, A.; Tufte, P. A. \& Christoffersen, L. (2016). Introduksjon til samfunnsvitenskapelig metode (4. utg.). Oslo: Abstrakt.

Kjeldstadli, K. (1999). Fortida er ikke hva den en gang var - en innføring i historiefaget. (2. utgave). Oslo: Universitetsforlaget.

Kvale, S. \& Brinkmann, S. (2017). Det kvalitative forskningsintervju. Oslo: Gyldendal Akademisk.

Malterud, K. (2006). Kvalitative metoder i medisinsk forskning. Oslo: Universitetsforlaget.

Meld. St. 20 (2012-2013). På rett vei - Kvalitet og mangfold i fellesskolen, Oslo:

Kunnskapsdepartementet Lastet ned 12.09. 2019 fra:

https://www.regjeringen.no/no/dokumenter/meld-st-20-20122013/id717308/

NOU 2003:19. Makt og demokrati. Sluttrapport fra makt- og demokratiutredningen. Lastet 25.11.2017 fra:

\section{https://www.regjeringen.no/contentassets/316f4765f7c44a2c8def9dcdb5da8f30/no/pd fs/nou200320030019000dddpdfs.pdf}

Nyen, T. \& Hagen Tøndel, A. (2014). Yrkesfagene under press. Oslo: Universitetsforlaget.

Olsen, O. J. (2008). Institusjonelle endringsprosesser i norsk fag- og yrkesutdanning. Fornyelse eller gradvis omdannelse? Rokkansenteret Notat 5-2008. Lastet ned 14.12.2017 fra: http://bora.uib.no/bitstream/handle/1956/4267/Notat\%2052008\%2001sen.pdf; sequence $=1$

Olsen, O. J. (2010). Tradisjon og fornyelse i norsk fag- og yrkesopplæring. Til spørsmålet om 'nytt helhetlig kvalitetssystem'. Norsk pedagogisk tidsskrift 2010, Volum 94 (6), s. 451-461. Lastet ned 12.09. 2019 fra: https://www.idunn.no/npt/2010/06/art05

Olsen, O. J. (2011). Yrkesutdanning i det moderne. Noen begreper til fortolkning av endringsprosesser i norsk fag- og yrkesopplæring. Sosiologisk tidsskrift, Volum 19, 01/2011, 29-47. Lastet ned 12.09. 2019 fra: https://www.idunn.no/st/2011/01/art05

Olsen, O. J., Høst, H. \& Michalsen, S. (2008). Veier fra yrkesopplæring til arbeidsliv, en studie av det norske overgangsregimets effektivitet. I J. Olofsson \& A. Panican (red.), 
Ungdommars väg från skola till arbetsliv. Nordiska erfarenheter (s. 249-332).

TemaNord 2008:584. København: Nordisk Ministerråd Latet ned 20.09. 2019 fra:

https://www.nordic-ilibrary.org/education/ungdomars-vag-fran-skola-till-

arbetsliv/veier-fra-yrkesopplaering-til-arbeidsliv-en-studie-av-det-norske-

overgangsregimets-effektivitet_9789289333139-9-sv

Postholm, M. B. (2010). Kvalitativ metode. En innføring med fokus på fenomenologi, etnografi og casusstudier. (2. utg.). Oslo: Universitetsforlaget.

Reegård, K, \& Høst, H. (2015). Fagopplæring eller statlig utdanning i arbeidslivet? Om lærefagene IKT Service og Kontor- og administrasjon. NIFU/Fafo. Rapport 2015:40 Lastet ned 20.09.2019 fra: https://www.nifu.no/publications/1315522/

Strøm Prestvik, A., Helgesen, H., \& Rålmnibio, P. C. (2016). Fag- og yrkesopplæring i matindustrien. NIBIO - rapport. VOL.: 2, NR.: 41, 2016. Lastet ned 25. 11. 2017 fra: https://www.udir.no/globalassets/filer/tall-og-forskning/forskningsrapporter/nibio.pdf

SRY og de faglige rådene i Norge (2017). Lastet ned 28.09.2019 fra:

https://fagligeradbackup.udir.no/

Sund, G. H. (2005). Forskjellighet og mangfold - muligheter eller begrensninger for individ og arbeidsplass? Et aksjonsforskningsprosjekt med studier av læring i daglig arbeid, gjennom medvirkning, demokratiske prosesser og interessedifferensiering. Phd avhandling, Roskilde Universitetscenter Forskerskolen Livslang Læring.

Thagaard, T. (2009). Systematikk og innlevelse. En innføring i kvalitativ metode. Bergen: Fagbokforlaget.

Utdanningsdirektoratet (2016a). Gjennomgang av det yrkesfaglige utdanningstilbudet. Lastet ned 15.12. 2016 fra: https://www.udir.no/globalassets/filer/fag-ogyrkesopplering/gjennomgang-av-det-yrkesfaglige-utdanningstilbudet.pdf.

Utdanningsdirektoratet (2016b). Gjennomgang av det yrkesfaglige utdanningstilbudet. Utdanningsdirektoratet sine anbefalinger til Kunnskapsdepartementet. Lastet ned 10.10. 2017 fra: https://www.udir.no/globalassets/filer/fag-ogyrkesopplering/gjennomgang-av-det-yrkesfaglige-utdanningstilbudet.pdf

Utdanningsdirektoratet (2017a). Høring av endring i den yrkesfaglige tilbudsstrukturen. Lastet ned 10.05.2017 fra: https://hoering.udir.no/Hoering/v2/131 
Utdanningsdirektoratet (2017b). Retningslinjer for samarbeid - SRY, faglige råd og Udir. Lastet ned 10.10. 2017 fra: https://www.udir.no/utdanningslopet/videregaendeopplaring/felles-for-fagopplaringen/retningslinjer-samarbeid-for-sry-fagligerad$\underline{\text { udir/3.-mandater/ }}$

Utdanningsdirektoratet (2018). Ny tilbudsstruktur for yrkesfaglige utdanninger. Lastet ned. 12. 03.2018. https://www.udir.no/laring-og-trivsel/lareplanverket/forsok-ogpagaende-arbeid/ny-tilbudsstruktur-og-nye-lareplaner-pa-yrkesfag/ny-tilbudsstrukturi-fag--og-yrkesoplaringen/

Utdanningsdirektoratet (2016c). Yrkesfaglig utvalg for bygg, industri og elektro. Lastet ned 12.09.2019 fra: https://www.udir.no/globalassets/filer/fag-ogyrkesopplering/yrkesfaglig-utvalg-for-bygg-industri-og-elektro.pdf

Utdanningsdirektoratet (2016d). Yrkesfaglig utvalg for helse, oppvekst og velvære. Lastet ned 12.09.2019. https://www.udir.no/globalassets/filer/fag-ogyrkesopplering/yrkesfaglig-utvalg-for-helse-oppvekst-og-velvare.pdf

Utdanningsdirektoratet (2016e). Yrkesfaglig utvalg for immateriell kulturarv og verneverdige fag. Lastet ned 12.09.201 fra: https://www.udir.no/globalassets/filer/samlesider/fagopplaring/sry/yrkesfaglig-utvalgfor-immateriell-kulturarv-og-verneverdige-fag.pdf

Utdanningsdirektoratet (2016f). Yrkesfaglig utvalg for kontor, handel og service. Lastet ned 12.09.2019 fra:

https://www.udir.no/globalassets/filer/samlesider/fagopplaring/yrkesfaglig-utvalg-forkontor-handel-og-service.pdf

Utdanningsdirektoratet (2016g). Yrkesfaglig utvalg for reiseliv, matproduksjon og primærnæring. Lastet ned 12.09.2019 fra: https://www.udir.no/globalassets/upload/fagopplaring/yrkesfaglig-utvalg-for-reiselivmatproduksjon-og-primarnaring_ny.pdf

Østerud Ø. Engelstad, F. \& Selle, P. (2003). Makten og demokratiet - en sluttbok fra Maktog demokratiutredningen. Oslo: Gyldendal Akademisk 


\section{Forfatterbiografier}

Kari Hansen, Førstelektor, Institutt for lærerutdanning ved NTNU.

Hansen underviser ved den treårige yrkesfaglærerutdanningen, leder nasjonale videreutdanningstilbud for yrkesfaglærere, eksterne oppdrag og er veileder på master i yrkesdidaktikk. Hun har begrunn som selvstendig næringsdrivende, som yrkesfaglærer i mange år innen design- og håndverk og har svennebrev som dame- og herrefrisør. Hennes forskningsinteresse er knyttet til yrkesopplæring med fokus på interesse-/yrkesdifferensiering, tidlig fordypning i Vg1, samt likestilling, makt og demokrati.

Grete Haaland, Professor, OsloMet - Storbyuniversitet

Haaland har jobbet som selvstendig næringsdrivende og yrkesfaglærer i mange år og har erfaring fra prøvenemnds- og nasjonalt klagenemndsarbeid. Hun er utdannet frisørmester og er i dag leder av Kompetansesenteret for Yrkesfag ved OsloMet. Hun har omfattende erfaring fra utdanningspolitisk arbeid, blant annet gjennom medlemsskap i opplæringsråd/faglig råd og læreplanarbeid. Hennes forskningsinteresse er knyttet til yrkesfag, yrkesopplæring med fokus på myndiggjøring, relevans og yrkesdifferensiering, anerkjennelse av realkompetanse, samt likestilling, makt, demokrati og trepartssamarbeid.

Inger Vagle, Førsteamanuensis, OsloMet - Storbyuniversitet Hun har jobbet som selvstendig næringsdrivende, har fagbrev som elektriker og elektroinstallatør og underviser ved den treårige yrkesfaglærerutdanningen ved OsloMet. Hennes forskningsinteresse er fagopplæring og likestilling. Inger Vagle har sammen med Ellen Møller fått tildelt LOs likestillingspris. 